\title{
THE DEMOGRAPHIC \\ CONSEQUENCES OF CHANGING \\ EMPLOYMENT OPPORTUNITIES: \\ Women in the Dutch Meierij \\ in the Nineteenth Century
}

\author{
MARLOU SCHROVER
}

\begin{abstract}
In the nineteenth century, the demographic development of the Meierij, a region in the south-east of the Netherlands, was different from that of the rest of modernizing northern Europe. Infant mortality remained high, while it dropped elsewhere. The article shows why the current explanation for high infant mortality, which links a sustained high infant mortality to a change in feeding habits, is not valid. Increased fertility due, among other reasons, to a lower marital age offers a better explanation. Changes in economic options open to unmarried women provide the clue. With fewer premarital occupational possibilities, women would have been more inclined to marry, or there would have been less pressure on them to forestall a marriage in order to profit to the full from the occupational options. More and earlier marriages meant more children were born, and also a higher infant mortality rate.
\end{abstract}

\section{THE MEIERIJ}

This research relates to four villages in the Meierij, a region in the south east of the Netherlands. Veghel and Schijndel are in the north of the Meierij, Aarle-Rixtel in the east, and Bladel in the south. Figure 1 shows the Meierij, its four major towns and the locations of the four villages. 's-Hertogenbosch was the largest city, and the capital of the almost homogeneously Catholic Meierij. From 1826,

Marlou Schrover is coeditor, with Gertjan de Groot, of Women Workers and Technological Change in Europe in the Nineteenth and Twentieth Centuries, London 1995.

THE HISTORY OF THE FAMILY An International Quarterly, Volume 2, Number 4, pages 451-480 Copyright $\odot 1997$ JAI Press Inc.

All rights of reproduction in any form reserved.

ISSN: 1081-602X 


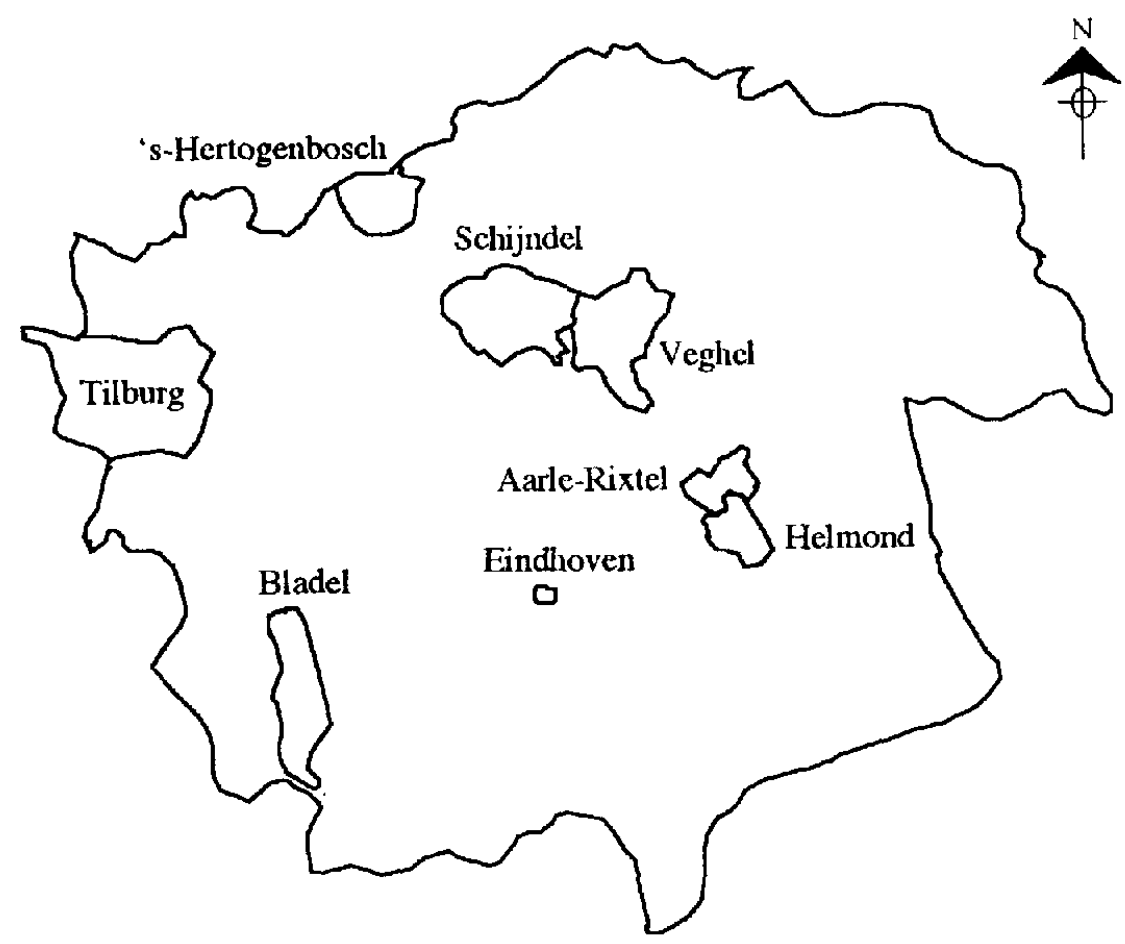

FIGURE 1

The Meierij with the Major Towns ('s-Hertogenbosch, Eindhoven, Tilburg and Helmond) and the Selected Villages (Schijndel, Veghel, Aarle-Rixtel and Bladel)

Veghel and Aarle-Rixtel were on a canal connecting "s-Hertogenbosch with Helmond. Veghel and Schijndel were about three times as large as Aarle-Rixtel and Bladel. Schijndel and Veghel each had a population of around 3500 in 1815 , and Aarle-Rixtel and Bladel 1100 each. Over a period of a hundred years the population of each of these villages increased by 80 percent, although growth rates were not the same per village and period.

For each village, three birth cohorts were studied: for Aarle-Rixtel and Bladel the cohorts of 1811, 1849, and 1889, and for Veghel and Schijndel the cohorts of 1829, 1849, and 1869. Each birth cohort consisted of 120 members, resulting in a total of 1440 cohort members. For the larger places, Schijndel and Veghel, the birth cohort of 1849 consisted of all births within that year. In the smaller places, Aarle-Rixtel and Bladel, the cohort contained all births during 1849, 1850, and 1851. For the earlier cohorts the periods were a bit longer. For the later cohorts they were slightly shorter. The ratio between the length of the period over which the births were taken in the smaller and the larger places was always three to one. Figure 2 shows the population of the Netherlands as a whole, that of Brabant, of which the Meierij was a part, and that of the four selected villages. Since devel- 


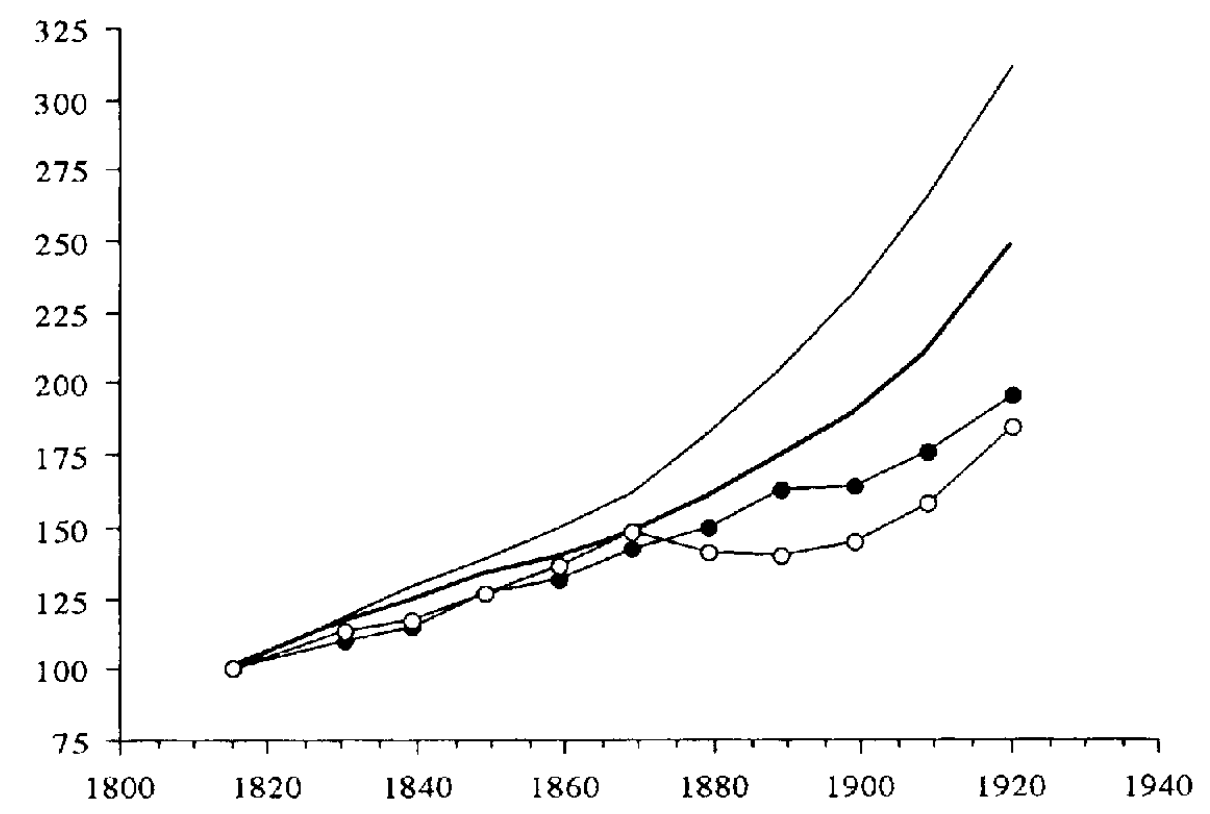

$\longrightarrow$ Netherlands $\longrightarrow$ Brabant $\longrightarrow$ Schijndel+Veghel $\longrightarrow-$ Bladel+Aarle-Rixtel

Source: E.W. Hofstee, Korte demografische geschiedenis van Nederland van 1800 tot heden, Haarlem 1981 , p.122-123; and data collected by the Landbouw Universiteit Wageningen, afd. Sociologie en sociografie, 'bevolkingsgegevens Brabantse gemeenten', by E.W. Hofstee.

FIGURE 2

Population of the Netherlands as a Whole, of Brabant, and of the Four Selected Villages 1815-1920 (index $1815=100$ )

opments in Schijndel and Veghel, on the one hand, and Bladel and Aarle-Rixtel, on the other, were similar, data are combined. Brabant lags behind when compared to the general Dutch growth, and the growth of the four villages is even slower. The population of Bladel and Aarle-Rixtel clearly drops after 1860 .

In the nineteenth century, the demographic development of the Meierij was different from that of the rest of modernizing northern Europe. Whereas Dutch birth rates decreased due to the demographic transition from about 1880 , in the Meierij birth rates rose. Moreover, death rates dropped considerably less in the Meierij than elsewhere. Infant mortality especially remained high, while elsewhere it diminished. Since the $1980 \mathrm{~s}$, a change from breastfeeding to bottlefeeding has become the accepted explanation for this failure for death rates to decline (Vandenbroeke, Van Poppel, and Van der Woude 1981, pp. 461-491; Meurkens 1984; Engelen and Klep 1996, p. 66; Duijvendak and Kooij 1992, p. 44). The only evidence for this change is found in a decrease in the length of the interval between 
births, which is used as a proxy for lactation. In this article, I argue that this decrease in the length of the interval can be explained by many other factors. One such factor is an increase in fertility. Fertility increased, as I hope to show, for two reasons. First, the marital age declined. Women are more fertile at a lower age, and the lower marital age lengthened the fertile period. Second, some of the most strenuous tasks which fell on women, mainly within the farmers household, disappeared in the course of the nineteenth century. Disappearance of this hard physical work also led to increased fertility. Increased fertility meant more children being born into already large households. The propensity to die was larger for children born into large families, or later in marriage (Van der Heijden 1995, p. 72-81; Thornton and Olson 1991, p. 411; Huck 1995, p. 541). Thus, when the birth rate rose, the death rate rose did also.

What is to be explained, therefore, is the decline in marital age, and decreased celibacy, rather than the high level of infant mortality. I argue here that changes in economic options open to unmarried women are the clue. In the course of the nineteenth century, some of the tasks of women, especially on farms, moved to men, both inside and outside farms. This change affected women farmers, but also-and more importantly-the female waged or unwaged help provided by maids, unmarried sisters, and daughters. Furthermore, the role of women as proto-industrial workers diminished, and opportunities for migrating female laborers disappeared. The change in the economic role of women was twofold. First, unmarried women saw a decrease in their occupational options. It is likely that women and men had a different marital behavior in relationship to their respective occupational options. Although statistics on labor participation of women are notoriously untrustworthy, it is clear that for most Dutch women marriage ended their waged labor participation outside the home. As marriage automatically ended a paid carrier, increased occupational opportunities would lead to postponement of marriage. With fewer premarital occupational possibilities, women were more inclined to marry, or there was less pressure on them to forestall a marriage in order to profit to the full from the occupational options. With fewer premarital occupational possibilitics the opportunity costs of marriage decreased. Since at the same time the occupational options open to men widened, more and carlier marriages were the result. Second, the economic role of women changed because married women working as farmers were gradually relieved of their most strenuous tasks. This had a positive effect on fertility. Both factors combined: more and earlier marriages and an increased fertility within marriage, led to a higher birth rate.

In what follows I hope to show why the current explanation for high infant mortality is not valid. Crucial in this argument is the length of the interval between births, as this is the only proof offered for a change in feeding habits. I show that the length of this interval is influenced by other factors beside breastfeeding. I also describe the change in the economic role of women.

\section{FERTILITY AND MORTALITY}

Until 1895, the birth rates for Brabant lie below the average of the Netherlands, as is shown in Figure 3. After 1880, the birth rate for the Netherlands starts to drop, whereas that of Brabant increases. Schijndel and Veghel are more or less in line with the figures for Brabant, whereas Bladel and Aarle-Rixtel are clearly different. From 1850 on, the birth rates for Bladel and Aarle-Rixtel remained well below that of Schijndel and Veghel, or 


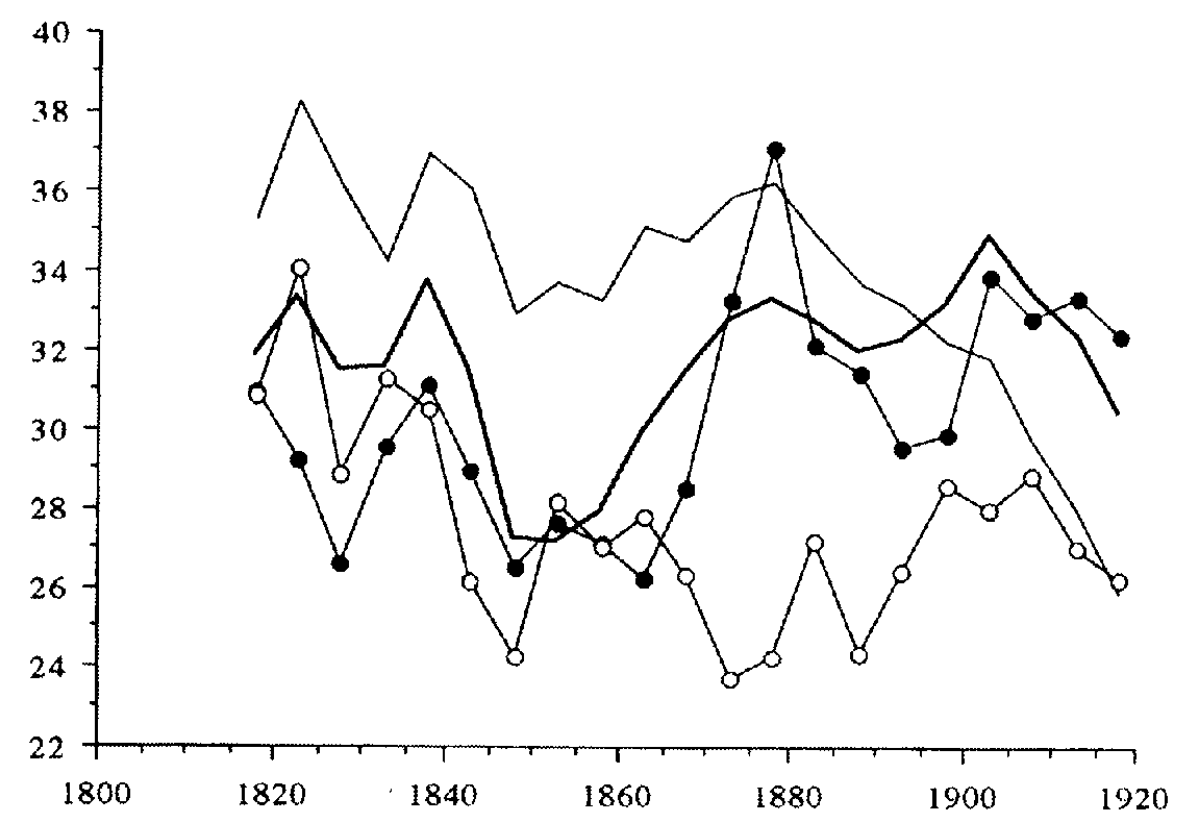

Netherlands - Brabant - Schijndel+Veghel - Bladel+Aarle-Rixte
Source: E.W. Hofstee, Korte demografische geschiedenis van Nederland van 1800 tot heden (Haarlem 1981)
122-123; and data collected by the Landbouw Universiteit Wageningen, dep. Sociologie en sociografie,
'bevolkingsgegevens Brabantse gemeenten', by E.W. Hofstee.

FIGURE 3

Birth Rates for the Netherlands as a Whole, for Brabant, and for the Four Selected Villages 1818-1918

Brabant in general. Bladel and Aarle-Rixtel were no exception as far as this low birth rate was concerned. Other peripheral places in the Meierij show the same low rate (Trienekens 1993, p. 226). This low birth rate is partly explained by the unbalanced sex-ratio caused by migration of people in their fertile years. The demographic effects of migration will be discussed below.

Toward the end of the nineteenth century, not only the birth rate was higher for Brabant than for the rest of the Netherlands, but also fertility was on the increase. In 1851-1855 fertility in Brabant, with 345 births per 1000 married women, was below the average for the Netherlands as a whole. In 1908-1911 fertility in Brabant had risen to 370 births per 1000 married women, whereas fertility in the Netherlands as a whole had fallen to 275 (Buissink 1970, p.84). At the end of the nineteenth century, Brabant not only experienced a larger number of births, but also more births per woman.

Until about 1880 , the death rates are lower for Brabant than for the Netherlands as a whole, as is shown in Figure 4. After 1880, the death rates of the Netherlands drop. The 


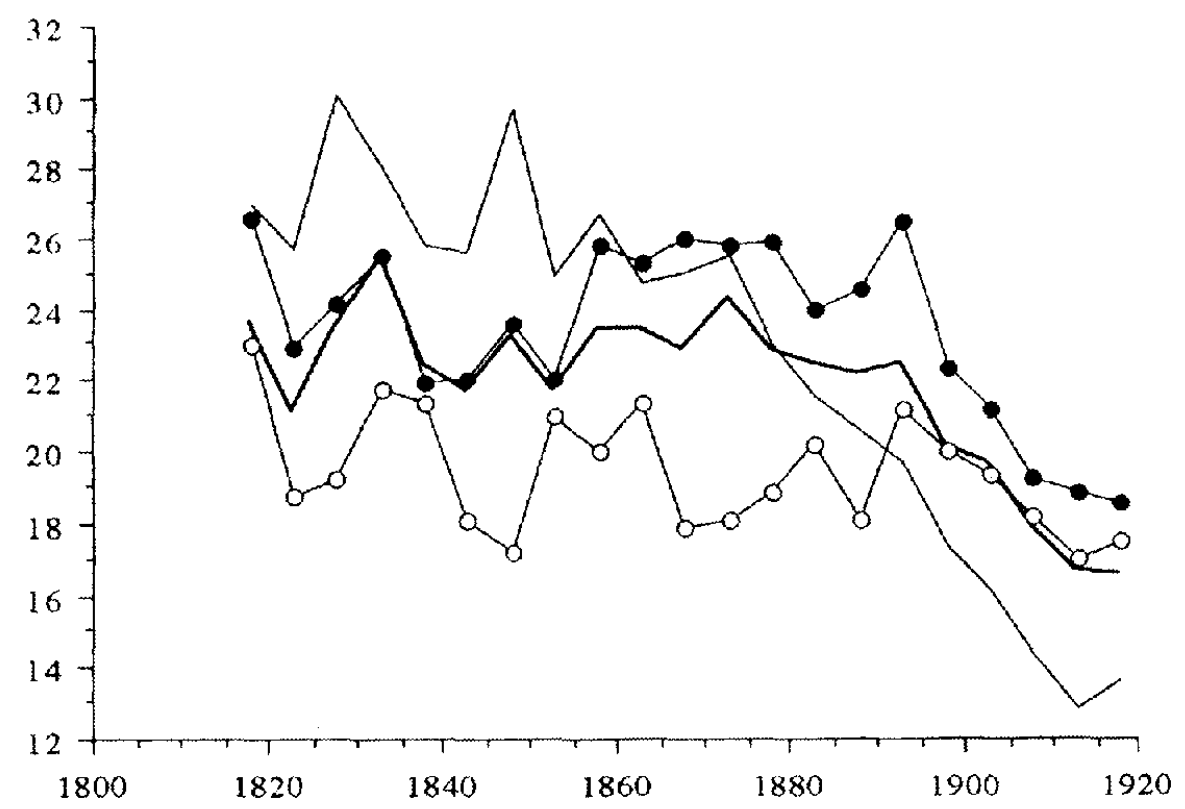

Netherlands $\longrightarrow$ Brabant $\longrightarrow$ Schijndel+Veghel -o- Bladel+Aarle-Rixtel

Source: E.W. Hofstee, Korte demografische geschiedenis van Nederland van 1800 tot heden (Haarlem 1981) 122-123; and data collected by the Landbouw Universiteit Wageningen, dep. Sociologie en sociografie, 'bevolkingsgegevens Brabantse gemeenten', by E.W. Hofstee.

\section{FIGURE 4}

Death Rates for the Netherlands as a Whole, for Brabant, and for the Four Selected Villages 1818-1918

death rates of Brabant also decline, but less rapidly. Schijndel and Veghel are more or less in line with the overall pattem for Brabant until 1850. After 1850 death rates increased. Bladel and Aarle-Rixtel clearly differ from this pattern with unusually low death rates until 1890. After 1890 the death rates rise to the high Brabant level. What sets Brabant apart from the rest of the Netherlands is that the birth rate does not drop, when elsewhere it does, and the death rate decreases less rapidly. Differences are most apparent at the end of the nineteenth century.

As infant death was the main component of the overall death figure, the difference in death rate between Brabant and the Netherlands as a whole is largely explained by a greater percentage of infants in the Brabant population. In the Meierij, late marriages and a high degree of celibacy were common until far into the nineteenth century. Elsewhere in the Netherlands, the transition to the modern marriage pattern, with carlier marriages and less 
celibacy, occurred before the first half of the nineteenth century (Hofstee 1978; van der Woude 1970, pp. 19-70).

In 1850, nuptiality in Brabant was considerably lower than in the Netherlands as a whole. However, contrary to the trend, nuptiality in Brabant continued to rise after 1880 . The percentage of men and women that were married before they were thirty years old also rose from 1880 on (Van Poppel 1992, pp. 239-242; Engelen and Hillebrand 1986 pp. 487-503). The high celibacy and late marriages during the first part of the nineteenth century help to explain the lower birth rates. The decrease in celibacy and earlier marriages explain the increase in births later in the century. This alone would account for the higher death rate in the second half of the century, because as a result children formed a larger part of the population (Van Poppel 1992, p. 119). However, not only the death rate was higher, but so is infant mortality. By 1895-1899, infant mortality in all provinces except Brabant had clearly dropped. Infant mortality did not increase in Brabant, but it dropped less than it did in the Netherlands as a whole (Hofstee 1983, pp. 7-60). It is important to note that not only infant mortality was higher in Brabant, but also mortality among women. In Brabant it took until 1920 for mortality among women to reach the level that it had in the Netherlands as a whole in 1900 (Van Poppel 1989, p. 368). Although at the end of the nineteenth century maternal mortality was still higher than elsewhere in the Netherlands, the average age at which women died did decrease in the course of the nineteenth century. In Aarle-Rixtel and Bladel, the age at which mothers died increased from, on average, 50 for the birth cohort of 1811 , to 67 for the birth cohort of 1849 .

\section{THE BREASTFEEDING HYPOTHESIS}

The main cause of infant death was intestinal ailments. In 1981, Vandenbroeke, Van Poppel and Van der Woude suggested that the regional differences in infant mortality could be explained by different feeding practices (Vandenbroeke, Van Poppel, and Van der Woude 1981, pp. 461-491). Hofstee, however, argued that the level of infant mortality was mainly determined by the quality of water (Hofstee 1978). They all agreed that infants who were breastfed stood a better chance of survival. They disagreed as to whether the main explanation for the regional difference could be found in feeding habits. Unfortunately, there are hardly any Dutch data on this (De Vooys 1951, pp. 223-271).

In 1925, the regional administration of Brabant conducted an extensive research into the relatively high infant mortality. They found as major causes ignorance, uncleanness, and bad housing. Some of the health committees-that were used as the major source of information-also reported malnutrition of women due to poverty as a cause of infant mortality. Frequent reference was made to the effects of the use of alcohol. Nourishing women drank beer believing that it would stimulate lactation. Young infants were given pacifiers made of bread crumbs soaked in brandy and wrapped in rags. Pregnant and nourishing women frequently got intoxicated, and drunken husbands maltreated their pregnant wives (Ildefonsus 1926). Although most contemporary authors accept the fact that housing, clothing, hygiene, knowledge about child care, readiness to call in medical help, and prenatal concern can make a large difference to the infant's chances to survive, they readily abandon these immeasurable factors in favour of the measurable birth intervals as a proxy for lactation. However, as Thomton and Olson have pointed out, this method 
makes any argument about causation tautological, as high birth rates are explained by high infant mortality, and vice versa. (Thornton and Olson 1991, pp. 401-417).

Babies were bottle-fed or fed on porridge when women were unable to breastfeed. An insufficient diet, physically strenuous work, and stress from the combination of farm work and the care for three or four small children reduced the quantity and quality of the mothers' milk. Vandenbroeke and his colleagues assumed that artificial feeding, and hence high infant mortality, in Brabant were caused by a more extensive labor participation of women in industry (Vandenbroeke, Van Poppel, and Van der Woude 1981, p. 113). This is not an uncommon assumption, although labor participation does not automatically exclude breastfeeding. A woman could feed her child before work, during the long noon break, after work, and twice at night. More importantly, however, Vandenbroeke et al. ignore the fact that labor participation of women in industry in the Netherlands was low. Married women almost never worked in industry. Vandenbroeke and his colleagues write that industries that bloomed later in the twentieth century, such as those of textiles, clothing, shoes, cigars, and electrical lamps, were already of importance in the last quarter of the nineteenth century. They assumed that this led to an increase in women's work, probably also of married women. Philips in Eindhoven, the largest producer of electric lamps, started up production in 1891 with 21 women and eight men. This quickly rose to 897 women and 276 men in 1909. All women at Philips were unmarried, and most were under eighteen (De Groot and Schrover 1995, p. 294). In the cigar industry, less then ten percent of the work force was female in 1899. Around 1900, the number of women employed in this industry fell due to the introduction of the bundle-machines, which made the inner work of the cigars, the ringing machines which put a paper band around the cigar, and the stripping machines which removed the stalks from the leaves. Since all this work had previously been done by women, these innovations meant their number decreased. In the clothing, textile, and shoe industries the number of women increased around 1900. Since female workers in these industries were young and unmarried, as they were at Philips, the increase in their number can not explain the high infant mortality. Lesthaeghe concluded that the breast-feeding hypothesis had been credited with too much explanatory power, but could not be dismissed altogether (Lesthaeghe 1983, pp. 61-84). In 1984, Meurkens proposed that high infant mortality, and the high birth rate, were caused by a decline in breastfeeding which was the result of a taboo on nudity imposed by the clergy, making it impossible for women to nurse their infants in public (Meurkens $1984 ; 1985 ; 1989$, pp. 117-130). Although it is true that prudery prevented children from being breastfed in public well into the nineties of the twentieth century, this does not mean they were not breastfed at all. Meurkens studied six villages located in the Meierij, east of Bladel. His evidence was largely based on circular reasoning whereby high birth rates were explained by high infant mortality, and vice versa. No proof was offered for an actual decline in breastfeeding. He found a significant decline in the length of the interval between the first to the sixth child born alive, from 23.8 months for the marriage cohort 1840-1850, to 17.2 for the marriage cohort 1900-1910. However, Meurkens did not adjust his figures to account for the increased mortality amongst neonatals in the last cohort. Nor does he take into account the effects of a fall of two years in the marital age of women. Furthermore, he dismisses the explanation of an increasing frequency in intercourse, although the region he studied was characterized by much seasonal labor and seasonal trade in the $1840 \mathrm{~s}$, both of which had disappeared by the end of the century. Meurkens found that in 1850 , six out of 105 women gave birth with average 
intervals of less than nineteen months. In 1880 this number had risen to thirteen out of 138 . He concluded, on this basis, that the number of non-breastfeeding mothers had doubled between 1850 and 1880 . Actually, this is only an increase from six percent in 1850 , to nine percent in 1880. According to Meurkens, increased fertility and shortened birth intervals first appeared amongst the higher and the lower strata of society. He explains this by a growing dependency of the lower on the higher strata, which stimulated women in the lower strata to imitate the behavior of the higher strata, and like them abstain from breastfeeding. All alternative explanations for the shorter intervals and the high infant mortality are dismissed without any argument. Surprisingly, despite its weak basis, this explanation caught on, and is widely cited as the explanation for high infant mortality (Engelen and Klep 1996, p. 66; Duijvendak and Kooij 1992, p. 44. See also Van der Heijden 1995, who wisely avoids Meurkens' thesis, but fails to find an alternative to feeding habits to explain the slow decrease in infant mortality. Like other authors he has no proof for a decrease in breastfeeding except the shortening of the intervals. Boonstra [1993, p. 295] questions Meurkens' theory, but does not investigate an alternative theory to any length).

\section{THE LENGTH OF THE BIRTH INTERVAL}

Of the 120 members in each birth cohort in the four villages of the present study, on average about a quarter died before reaching adulthood, and another quarter married within the village. The rest either did not marry or moved away. As some of the cohort members married other cohort members, and some marriages proved infertile, 318 families remained for which birth intervals and infant mortality could be measured. In total 1947 children were born. There are clear differences per village, as is shown in Table 1. In Veghel and,

TABLE 1

Number of Marriages and Births per Birth Cohort of 120 Members, Median Age of Women at Marriage, Birth of the First Child and Birth of the Fourth Child.

\begin{tabular}{|c|c|c|c|c|c|c|c|}
\hline \multirow[b]{2}{*}{ Birth Cohort } & \multirow[b]{2}{*}{$\begin{array}{l}\text { Number of } \\
\text { Marriages }\end{array}$} & \multirow[b]{2}{*}{$\begin{array}{c}\text { Period in Which } \\
\text { Births Fall }\end{array}$} & \multirow{2}{*}{\multicolumn{2}{|c|}{ Number Births per }} & \multicolumn{3}{|c|}{ Median Age Woman at } \\
\hline & & & & & Marriage & $\begin{array}{l}\text { Birth } \\
\text { First }\end{array}$ & $\begin{array}{l}\text { Birth } \\
\text { Fourth }\end{array}$ \\
\hline Bladel 1811 & 25 & $1830-1855$ & 154 & 6.2 & 27.9 & 26.0 & 32.6 \\
\hline Bladel 1849 & 30 & $1870-1895$ & 167 & 5.6 & 27.3 & 28.0 & 35.3 \\
\hline Bladel 1889 & 28 & $1910-1935$ & 198 & 7.1 & 25.7 & 27.0 & 32.1 \\
\hline Aarle 1811 & 20 & $1830-1855$ & 106 & 5.3 & 28.3 & 29.5 & 34.3 \\
\hline Aarle 1849 & 20 & $1870-1895$ & 103 & 5.2 & 29.9 & 32.0 & 36.2 \\
\hline Aarle 1889 & 16 & $1910-1935$ & 97 & 6.1 & 26.6 & 29.0 & 31.2 \\
\hline Schijndel 1829 & 23 & $1850-1875$ & 131 & 5.7 & 29.3 & 30.0 & 36.5 \\
\hline Schijndel 1849 & 22 & $1870-1895$ & 112 & 5.1 & 29.2 & 30.0 & 35.0 \\
\hline Schijndel 1869 & 30 & $1890-1915$ & 182 & 6.1 & 25.5 & 27.0 & 31.0 \\
\hline Veghel 1829 & 26 & $1850-1875$ & 171 & 6.6 & 26.7 & 28.0 & 32.2 \\
\hline Veghel 1849 & 41 & $1870-1895$ & 256 & 6.2 & 27.4 & 29.0 & 34.3 \\
\hline Veghel 1869 & 37 & $1890-1915$ & 270 & 7.3 & 26.6 & 28.5 & 31.9 \\
\hline Total & 318 & & 1947 & 6.1 & & & \\
\hline
\end{tabular}


to a lesser extent, Schijndel, more cohort members died before reaching adulthood, and more cohort members married within the village. More people-especially womenmoved away from Bladel and Aarle-Rixtel. In the later ycars the number of marriages per birth for all cohorts rose except in Aarle-Rixtel where they fell. In Bladel and Veghel the number of births per marriage was higher than in Aarle-Rixtel and Schijndel. Veghel combined a high number of marriages with a high number of births.

Breastfeeding is not a reliable contraceptive, but it does decrease a woman's fertility. A new pregnancy does not automatically end lactation, and children can be breastfed well into the fifth month of the next pregnancy. At the end of the nineteenth century, infants who were bottlefed during the first thirty weeks after birth stood a much higher chance of dying than breastfed infants (Kintner 1985, p. 163; Van Poppel 1982, p. 260). Infant mortality amongst bottlefed children was ten to 30 percent higher than that amongst breastfed infants (Knodel 1977). The higher mortality was caused, amongst other things, by cow's milk being diluted with water for bottle-feeding. Impure water and insufficient cleansing of the bottles caused digestion problems, and often the child's death.

When discussing the effects of breastfeeding on the length of the interval between births, and on fertility and infant mortality, it is important to specify the duration of this feeding. We can globally distinguish between three periods: six weeks, six months, or two years. Breastfeeding during the first six weeks will have had little effect on the woman's fertility, as this falls within the period of the post-partum amenorrhea, but will have given infants a

TABLE 2

Number of First to Fifteenth Children per Birth Cohort

\begin{tabular}{lrrrrrrrrrrrrrrr}
\hline & 1 & 2 & 3 & 4 & 5 & 6 & 7 & 8 & 9 & 10 & 11 & 12 & 13 & 14 & 15 \\
\hline Bladel & & & & & & & & & & & & & & & \\
1811 & 25 & 23 & 22 & 20 & 17 & 14 & 10 & 9 & 7 & 4 & 3 & 0 & 0 & 0 & 0 \\
1849 & 30 & 29 & 26 & 22 & 18 & 16 & 11 & 8 & 4 & 1 & 1 & 1 & 1 & 0 & 0 \\
1889 & 28 & 28 & 27 & 26 & 21 & 17 & 15 & 11 & 10 & 7 & 4 & 3 & 1 & 0 & 0 \\
Aarle & & & & & & & & & & & & & & & \\
1811 & 20 & 18 & 15 & 14 & 12 & 10 & 7 & 4 & 2 & 1 & 1 & 1 & 1 & 0 & 0 \\
1849 & 20 & 17 & 17 & 12 & 9 & 7 & 3 & 3 & 3 & 3 & 2 & 2 & 2 & 2 & 1 \\
1889 & 16 & 15 & 13 & 11 & 8 & 7 & 6 & 6 & 5 & 3 & 3 & 1 & 1 & 1 & 1 \\
Schijndel & & & & & & & & & & & & & & & \\
1829 & 23 & 21 & 20 & 18 & 15 & 11 & 8 & 7 & 3 & 2 & 1 & 1 & 1 & 0 & 0 \\
1849 & 22 & 20 & 19 & 15 & 10 & 10 & 6 & 5 & 3 & 2 & 0 & 0 & 0 & 0 & 0 \\
1869 & 30 & 28 & 26 & 24 & 21 & 19 & 14 & 8 & 6 & 4 & 1 & 1 & 0 & 0 & 0 \\
Veghel & & & & & & & & & & & & & & & \\
1829 & 26 & 26 & 23 & 20 & 16 & 13 & 13 & 10 & 9 & 7 & 6 & 1 & 1 & 0 & 0 \\
1849 & 42 & 37 & 36 & 32 & 28 & 22 & 15 & 13 & 10 & 8 & 6 & 4 & 1 & 1 & 1 \\
1869 & 37 & 37 & 34 & 31 & 23 & 20 & 19 & 16 & 13 & 11 & 10 & 8 & 7 & 3 & 1 \\
Total & 318 & 299 & 278 & 245 & 198 & 166 & 127 & 100 & 75 & 53 & 38 & 23 & 16 & 7 & 4 \\
Death & 23 & 28 & 27 & 27 & 20 & 22 & 7 & 11 & 12 & 7 & 7 & 4 & 1 & 0 & 1 \\
Between & & & & & & & & & & & & & & & \\
$29-365$ & & & & & & & & & & & & & & & \\
Days & & & & & & & & & & & & & & \\
$\%$ & 7.2 & 9.4 & 9.7 & 11.0 & 10.1 & 13.3 & 5.5 & 11.0 & 16.0 & 13.2 & 18.4 & 17.4 & 6.3 & 0 & 25 \\
\hline
\end{tabular}


better start in life compared to children that were not breastfed at all. After the first thirty weeks, the child would have started teething, and required supplements to milk. Having survived more than the critical first half year, breastfeeding could be reduced without the excessive health risks of the earlier months (Hofstee 1983, p. 31). Although caloric requirements of the child will make it difficult to raise it only on mothers milk much beyond the first half year, protection from contagious diseases by partial breastfeeding can be offered until the child is well over one year old. Partial breastfeeding, where the child got supplements like pap in addition to mother's milk, exposed the child to the risks of contaminated water or food, but protected it from contagious diseases such as chicken-pox, German measles, smallpox, scarlet fever, whooping-cough, and a row of other diseases. It is important to distinguish between the effects of lactation on fertility, on the one hand, and on the infant's health, on the other. A long lactation period, over twenty months, may have affected fertility, but its effects on infant mortality are probably negligible (Hofstee 1983, p. 45; Lesthaeghe and Page 1980, pp. 143-169). Lactation for more than a year is of little importance when explaining infant mortality.

The propensity to die was not equal for all children. Table 2 shows all births per birth cohort, and the overall number of deaths that might have been related to nourishing practices, hence the deaths between 29 and 365 days. With each new birth the chance the child died increased (Boonstra 1993, p. 297). This birth rank related infant mortality need not have been 'mortality by neglect', but could also be 'mortality of exhaustion', as each new birth exhausted both the material means of the families and the physical reserves of the mother.

The average length of the interval between one birth and the next decreased in the course of the nineteenth and the beginning of the twentieth century. This shortening may have been the result, as Meurkens argued, of a change in feeding habits. It may, however, also have been caused by a higher infant mortality. Without any further information it is impossible to decide whether infant mortality was the result of artificial feeding, reflected in the length of the interval, or whether shorter intervals reflected a higher infant mortality. Some indications of the cause of the shortening of intervals can be found by separating infant mortality into nourishment-related deaths, and non-nourishment-related deaths. Endogene deaths, between one and 28 days after birth, are unlikely to be related to nourishment practices. Deaths within the period of post-partum amenorrhea (PPA) may have been caused by feeding habits, but do not affect women's fertility, and thus do not shorten the length of the interval. Furthermore, the interval between the birth of one child and the next will not only be shorter if the child is not breastfed, but also if the child is born dead. The length of the interval is also affected by the number of miscarriages and changes in fecundity.

\section{STILLBIRTHS, MISCARRIAGES, AND FECUNDITY}

Stillbirths reduce the length of the interval after birth, but also before. After a stillbirth, the interval is shortened because the woman does not nourish a child. The minimal length of the interval between a stillbirths and the next birth will be nine months plus the period of the post-partum amenorrhea (PPA). As the length of the PPA varies from one to three months, the minimal length of the interval after a stillbirth will be ten to twelve months. The interval before a stillbirth can be shorter because stillbirths result partly from children not being carried to the end of term. The interval before a stillbirth can be shortened by two 
TABLE 3

Number of Still Births and Infant Deaths per Village and Birth Cohort

\begin{tabular}{|c|c|c|c|c|c|c|c|c|c|c|}
\hline \multirow[t]{2}{*}{$\begin{array}{c}\text { Birth } \\
\text { Cohort }\end{array}$} & \multirow[t]{2}{*}{$\begin{array}{c}\text { Still } \\
\text { Births }\end{array}$} & \multirow[t]{2}{*}{$\begin{array}{c}\text { Endogene } \\
\text { Death }\end{array}$} & \multirow[t]{2}{*}{$\begin{array}{l}\text { Death } \\
\text { in Ppa }\end{array}$} & \multicolumn{2}{|c|}{$\begin{array}{c}\text { Total Non- } \\
\text { nourishment } \\
\text { Related } \\
\text { Deaths }\end{array}$} & \multicolumn{2}{|c|}{$\begin{array}{c}\text { TotalPossibly } \\
\text { Nourishment } \\
\text { Related } \\
\text { Deaths }\end{array}$} & \multicolumn{2}{|c|}{$\begin{array}{c}\text { Total Infant } \\
\text { Death }\end{array}$} & \multirow[t]{2}{*}{$\begin{array}{c}\text { Total } \\
\text { Number } \\
\text { of Births }\end{array}$} \\
\hline & & & & a & $\%$ & a & $\%$ & $\mathrm{a}$ & $\%$ & \\
\hline Bladel 1811 & 5 & 4 & 4 & 8 & 52 & 4 & 26 & 12 & 78 & 154 \\
\hline Bladel 1849 & 4 & 10 & 3 & 13 & 78 & 6 & 36 & 19 & 114 & 167 \\
\hline Bladel 1889 & 7 & 2 & 3 & 5 & 25 & 6 & 30 & 11 & 50 & 190 \\
\hline Aarle 1811 & 14 & 0 & 3 & 3 & 28 & 1 & 9 & 4 & 38 & 106 \\
\hline Aarle 1849 & 3 & 6 & 3 & 9 & 87 & 12 & 117 & 21 & 204 & 103 \\
\hline Aarle 1889 & 4 & 0 & 2 & 2 & 20 & 2 & 21 & 4 & 41 & 97 \\
\hline Schijndel 1829 & 0 & 10 & 3 & 13 & 99 & 15 & 115 & 28 & 214 & 131 \\
\hline Schijndel 1849 & 9 & 5 & 2 & 7 & 63 & 8 & 71 & 15 & 134 & 112 \\
\hline Schijndel 1869 & 11 & 14 & 2 & 16 & 88 & 16 & 88 & 32 & 176 & 182 \\
\hline Veghel 1829 & 10 & 7 & 11 & 18 & 105 & 22 & 129 & 40 & 234 & 171 \\
\hline Veghel 1849 & 21 & 9 & 14 & 23 & 90 & 23 & 90 & 46 & 180 & 256 \\
\hline Veghel 1869 & 27 & 12 & 15 & 27 & 100 & 17 & 63 & 44 & 163 & 270 \\
\hline Total & 115 & 79 & 65 & 144 & 74 & 132 & 68 & 276 & 141 & 1947 \\
\hline
\end{tabular}

months. These short intervals did actually occur. In six cases the interval between the birth of one child and its still- born successor was extremely short: between 6.5 and 9.7 months.

In the case of a stillbirth, endogene death of the child, or death within the PPA, the length of the interval to the next child need not be more than nine months plus the length of the PPA. An increase in the number of stillbirths, endogene deaths, and death within the PPA period will lead to a shortening of the interval. On the total number of 1947 births, 182 children (nine percent) were born after their predecessor was born dead, or died before being 90 days old. In 27 cases this resulted in an interval of less than a year. Another 91 children were born within a year and a half. Only in 64 cases the interval was longer. Table 3 specifies these data per village and per birth cohort. Some caution has to be used when interpreting these data. For instance, the strikingly high number of stillbirths in the birth cohort of Aarle 1811 is caused by one woman who saw seven out of her thirteen pregnancies end in a stillbirth. Children born alive in this family all survived their first year. This phenomenon, that many children within one family died of apparently the same cause, has also been noted by other authors (Thornton and Olson 1991, p. 410). It could be caused by a poor physical condition of the mother, or by insufficient obstetrical help. Table 3 shows an increase in infant mortality for Aarle-Rixtel and Bladel in children born to the birth cohort of 1849. Later, infant mortality declined. In Bladel, the increase is mainly caused by a rise in the number of endogene deaths. In Aarle-Rixtel there is a rise in the number of both endogene, and other infant deaths. Schijndel and Veghel show a decrease in infant mortality amongst children born to the birth cohort of 1849. In Veghel, and to a lesser extent Schijndel, the number of stillbirths and endogene deaths increased in the latter, whereas the other types of death were on the decline. The overall picture is that the number of stillbirths and of the other types of infant mortality tend to move in the same direction. 
Altogether, the number of possibly nourishment-related deaths fluctuates in the same direction as that of the unrelated deaths. This makes it unlikely that the cause of deaths was feeding habits only.

The stillbirths and endogene deaths cannot be attributed to nourishment practices. The number of stillbirths and endogene deaths may have been influenced by the availability of obstetrical help. It is not likely that obstetrical help in these four villages improved much in the course of the nineteenth century. The smaller places Aarle-Rixtel and Bladel did not have a midwife or a doctor. Of the larger villages, Schijndel had two doctors in the second half of the nineteenth century, and Veghel had three to four. In the second half of the century, neither of these places had a midwife, although a midwife is reported in each village in the first half of the century.

In addition to stillbirths and infant mortality, miscarriages also influence the length of the interval. Even today, however, there are no reliable data on the number of miscarriages. Nowadays, as a rule of thumb, it is assumed that one in five pregnancies ends in a miscarriage. Miscarriages can have many causes, among which physical and psychological stress, malnutrition, and bacterial or virus infections (such as German measles). It is not unreasonable to assume that the number of miscarriages and the number of stillbirths are related. It has been suggested that on average there were seven times as many miscarriages as still-

TABLE 4

The Average Length of the Interval, in Months Between Marriage and the Birth of the First Child, between the Birth of the First and the Second Child and so on for Each Birth Cohort. Intervals are Only Included if the Child was Born Alive and the Child Born before Survived the First Year

\begin{tabular}{lccccccccc}
\hline & $m-1$ & $1-2$ & $2-3$ & $3-4$ & $4-5$ & $5-6$ & $6-7$ & $7-8$ & $\begin{array}{c}\text { Average } \\
\text { Births Only }\end{array}$ \\
\hline Bladel & & & & & & & & & \\
1811 & 16.8 & 28.3 & 27.9 & 27.8 & 27.8 & 26.2 & 23.7 & 30.4 & 27.4 \\
1849 & 21.8 & 21.2 & 26.9 & 30.6 & 26.2 & 23.4 & 24.2 & 28.7 & 25.9 \\
1889 & 11.7 & 18.9 & 23.5 & 21.3 & 28.5 & 24.9 & 30.6 & 22.9 & 24.4 \\
Aarle & & & & & & & & & \\
1811 & 23.9 & 32.7 & 27.1 & 25.1 & 28.5 & 29.0 & 31.2 & 31.3 & 29.3 \\
1849 & 16.9 & 22.3 & 19.9 & 28.8 & 25.7 & 26.0 & 18.3 & 17.9 & 22.7 \\
1889 & 12.9 & 20.9 & 27.1 & 23.4 & 27.2 & 25.4 & 19.5 & 23.3 & 23.8 \\
Schijndel & & & & & & & & & \\
1829 & 13.1 & 19.1 & 22.7 & 34.1 & 32.2 & 28.9 & 24.4 & 29.7 & 27.3 \\
1849 & 15.2 & 22.0 & 22.3 & 30.2 & 26.8 & 25.7 & 13.6 & 23.5 & 23.4 \\
1869 & 12.2 & 17.8 & 19.2 & 20.8 & 24.1 & 26.9 & 26.7 & 22.4 & 22.6 \\
Veghel & & & & & & & & & \\
1829 & 11.0 & 18.9 & 25.0 & 20.2 & 27.5 & 18.9 & 19.5 & 22.4 & 21.8 \\
1849 & 25.9 & 22.2 & 21.4 & 23.5 & 25.3 & 28.5 & 23.1 & 23.0 & 23.9 \\
1869 & 19.1 & 16.2 & 20.7 & 22.1 & 18.3 & 17.6 & 24.8 & 20.6 & 20.0 \\
Total & 17.1 & 21.3 & 23.5 & 25.4 & 26.2 & 25.3 & 24.7 & 24.5 & 24.4 \\
n=648 & & & & & & & & & \\
\hline
\end{tabular}


births (Hofstee 1983, p. 26). For places with relatively few stillbirths, such as Bladel and Aarle-Rixtel in most years, this would result in one miscarriage in five children born alive. In places with many stillbirths, such as Schijndel and Veghel in most years, this would mean two to three miscarriages in five children born alive. As each miscarriage tends to lengthen the interval between one birth and the next by two to five months, a decreasing number of miscarriages will lead to shorter intervals.

The ability to conceive (fecundity) also influences the length of the interval. Miscarriages and stillbirths are caused by, or resulted in, problems that reduce fecundity. A decrease in the number of miscarriages and stillbirths affected fecundity and shortened the length of the interval. Like miscarriages and stillbirths, fecundity is inlluenced by physical and psychological stress, malnutrition, and infections. The average length of the interval between marriage and the birth of the first child is used as an indication for fecundity (Thornton and Olson 1991, p. 409). For all villages taken together the average was seventeen months (see Table 4). It must be taken into account, however, that the average length of this interval is influenced by conceptions before marriage. If all births are omitted that occurred within less than nine months after the wedding, the interval between marriage and the birth of the first child becomes nineteen months. This indicates a low marital fertility because other studies report an average of ten months (Thornton and Olson 1991, p. 409).

The number of stillbirths, infant deaths, and miscarriages, and the degree of fecundity and maternal mortality are related phenomena. All can be explained by the level of obstetrical help. On the whole, obstetrical help in the countryside, in particular in the south and the east of the Netherlands, was much worse than in towns. This resulted in a much higher death rate from complications during pregnancy and childbirth (Van Poppel 1989, p. 370). The lack of obstetrical help can probably account for part of the relatively late decline in infant mortality.

Table 4 shows the average length of the interval between consecutive children in months. Only those intervals are included that relate to children born alive and preceded by a child that did survive the first year. Thus effects of differences in the number of stillbirths and of the infant mortality rate are accounted for. Only the first eight births are included. Excluding stillbirths or births following infant death decreases the length of the interval by six months for Aarle-Rixtel, and nearly two months for Veghel. Even so, the average intervals reported in Table 4 do not support the hypothesis that children were not breastfed in later years. It is commonly assumed that an interval of more than eighteen months between a child born alive and a surviving predecessor indicates that children were breastfed (Thornton and Olson 1991, p. 409; Nault, Desjardins, and Légaré 1990, pp. 273-285; Hofstee 1983, p. 26). Hence in all years, both the earlier and the later, and in all villages the length of the interval was sufficiently long to allow breastfeeding.

Figure 5 shows the average interval between consecutive children in all four villages. The length of the interval depends on its place in the row of births. The first interval, between marriage and the birth of the first child, is not very informative as it also includes women marrying while already pregnant. From the second to the fifth child, the intervals lengthened with each birth. This could have been caused by attempts to control the number of births by spacing. Breastfeeding could have been used as a method to reduce fertility, but so could coitus interruptus, or abstinence. None of these methods were secure techniques of birth control, and all required knowledge and self-discipline. As the intervals shortened in the course of time (see Table 4) this would mean birth control decreased as the nineteenth century 


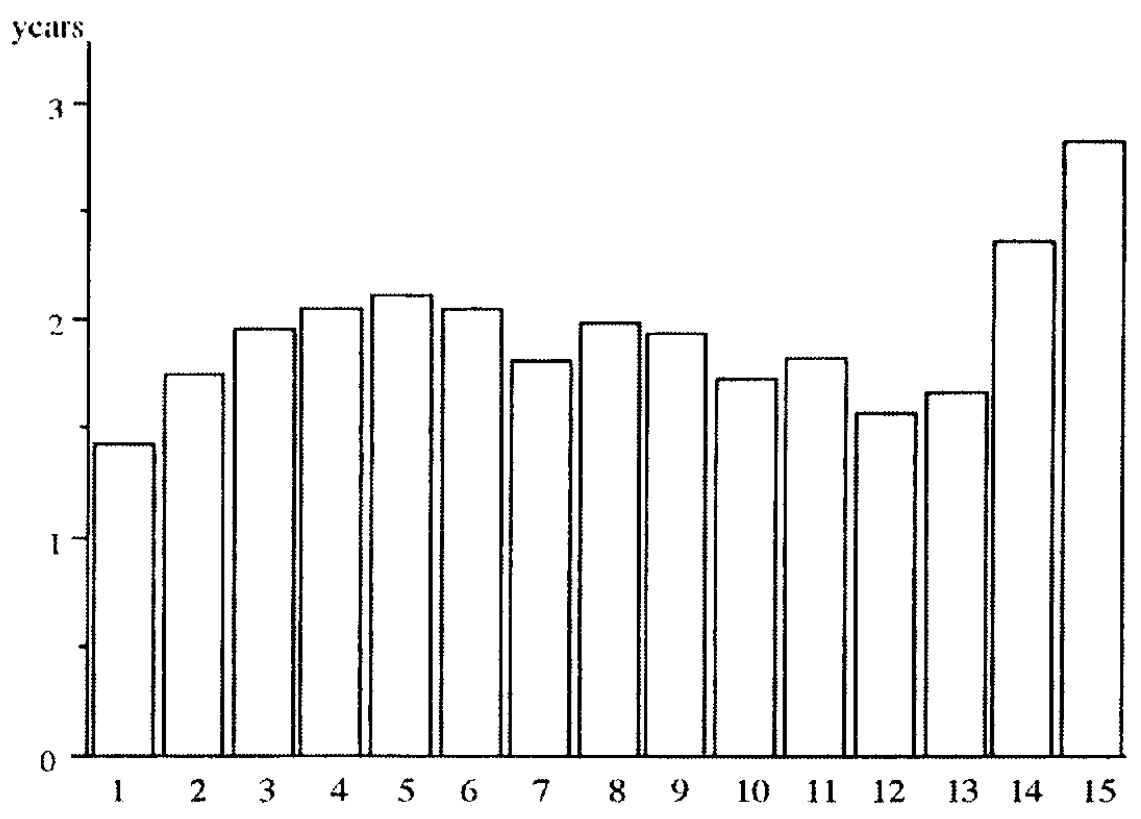

FIGURE 5

Average Length of the Interval between Marriage and the Birth of the First Child, Respectively Each Child and the Next, All Years and Places Taken Together

progressed. This does not sound very plausible. A much simpler explanation can be found in the age of the mother. Fertility of women declines after 24 . With a progressing age, the decline becomes steeper. A relatively high age at marriage, around 28 , means that a woman was around 34 at the birth of her fourth child (see Table 1). Fertility at 34 is only 75 percent of that at 28 (Coale and Treadway 1986, pp. 31-181).

After the fifth birth, the interval declines. This may appear to contradict the preceding account relating the increasing intervals to the mother's age. However, the decline is caused by the obvious link between numerous births and small intervals. In order to bear many children a woman had to marry young. After the birth of the thirteenth child, the average length of the interval rises again. By then even women who had married young were well over 40. The case of farmers Hendrik Tijssen (birth cohort Bladel 1849) and Johanna Dirks (born in Bladel 1852) is typical for the common interval pattern. They married when he was 29 and she 26 . They had six children during the first ten years of their marriage. The average interval between births was twenty months. After the birth of the sixth child, another three children were born, with much longer intervals: 32,44 , and 51 months. When the last child was born, Johanna was 46 .

The interval between births lengthens with an increasing age of the mother. In Figure 6 the length of the interval, corrected for infant mortality and stillbirthss, is combined with 
the age of mothers for the birth cohorts Schijndel 1829 and 1869 . Figure 6 shows that the slope of both lines is almost the same (the regression coefficient is 24 for 1829 and 20 for 1869), but that the intercept differs. This means that in both years the length of the interval increases with age. When not corrected for the age of the mother the decrease of the length of the interval between 1829 and 1869 was almost five months (Table 4). Corrected for the age of the mother it is less than two months. A large part of the shortening of the interval can thus be explained by a declining marital age. Women of the birth cohort 1869 started having children younger than those of the birth cohort 1829. This change is shown in Figure 7.

A decrease in the marital age not only increased the possible number of children because of a lengthened fertile period, but also because of the greater fertility at a younger age. The shift to the left (shown in Figures 6 and 7) is reflected in shorter intervals. In Schijndel the average marital age of women fell by almost four years from 29.3 in 1829 to 25.5 in 1869 (sce Table 1). The age at which women got their first child decreased by three years; that at which they got their fourth child was more than five years. In Aarle-Rixtel and Bladel

\section{interval}

in years

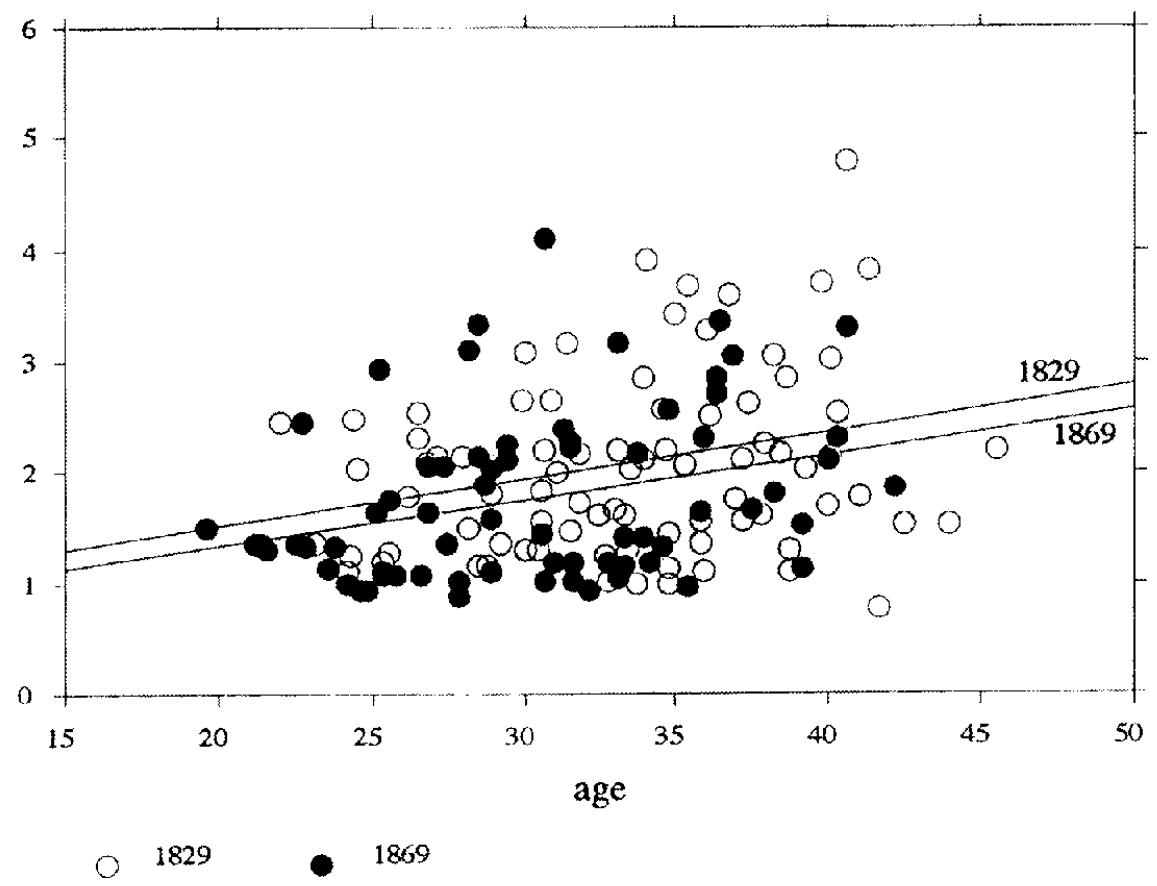

FIGURE 6

Age of the Mother and Length of the Birth Interval for Birth Cohorts Schijndel 1829 and 1869 


\section{number \\ of births}

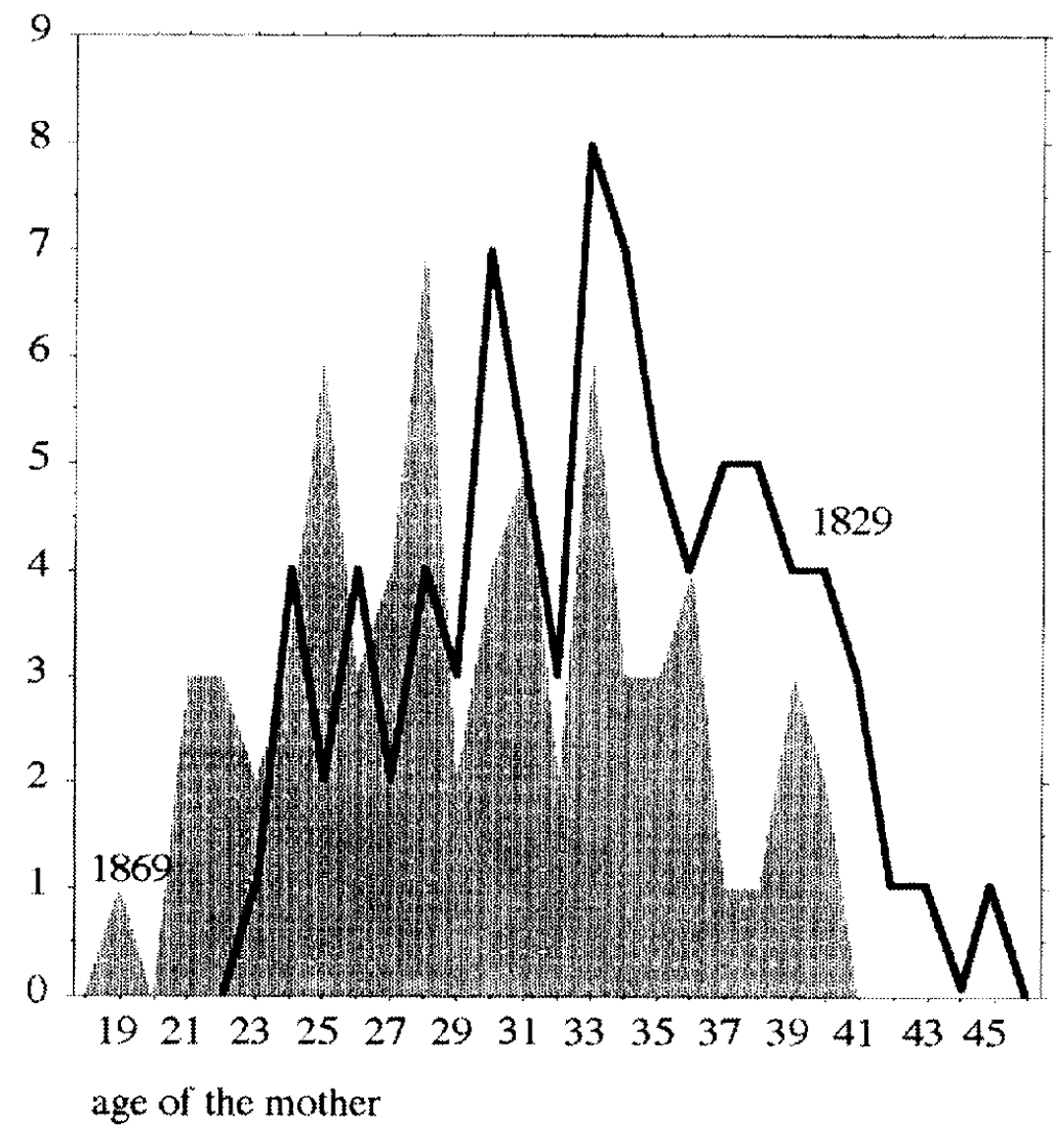

FIGURE 7

Number of Births per Age of a Mother for the Birth Cohorts Schijndel 1829 and 1869

the marital age of women fell by two years. In Aarle-Rixtel this resulted in a decrease of the age at which women gave birth to their fourth child of over three years. In Bladel the effect is less apparent. In Veghel the marital age hardly changed between the earlier year and the later. When studied more closely, the Veghel data reveal that, although the modal shifted to 25, like in Schijndel, the average did not decrease because as at the same time the number of marriages at about 34 years of age increased. Apparently there were reasons for some women to marry at an earlier age, while at the same time other women who were already past the common marital age found reasons to enter marriage after all. Times were favorable for marriage. The changes in marital age are in line with those in the length of the inter-birth 
intervals (see Table 4). In Schijndel and Aarle-Rixtel the intervals shortened most, like the marital age. In Veghel the change in the length of the birth interval was smaller.

The decreased marital age explains the high fertility in Brabant. The marital age also decreased in the rest of the Netherlands, but, although comparison is difficult due to differences in measurement technique, the fall in age in Brabant was probably about half a year more than in the Netherlands as a whole (Poppel 1992). Furthermore, the decrease in marital age in the rest of the Netherlands was accompanied by a decrease in fertility. Van Poppel has explained the decrease in fertility outside Brabant by more knowledge about and acceptance of birth control. According to Van Poppel $(1989$, p.390), the advantages of practicing birth control were greater in the west and the north. Moreover, birth control was considered morally acceptable at an earlicr date in the west and the north, and, as a consequence, contraceptives were introduced earlier and were more widely available. The only other province to experience an increased fertility was Limburg, which like Brabant and unlike the rest of the Netherlands was homogeneously Catholic.

\section{HOUSEHOLD STRATEGIES AND PROTOINDUSTRY}

Originally, a decreasing marital age was linked to proto-industrialization. The idea that proto-industrialization is responsible for a decline in marital age was developed by Kriedte, Medick, and Schlumbohm (Medick 1976; Kriedte, Medick, and Schlumbohm 1992). In recent years, they have adjusted their theory on proto-industrialization, acknowledging that the proto-industrial household was not always a production unit with a division of labor and co-operation between family members (Kriedte, Medick, and Schlumbohm 1993). Knodel has questioned the view that proletarianization led to lower marriage ages and higher fertility by showing that the marital age of wives of landless laborers was higher than average (Knodel 1988). Marriage and household formation were not always a necessary precondition for earning an independent income. Young people left their parents' homes several years before marriage, obtaining board and lodging elsewhere, and earning an independent wage. The connection between the work-process and the family as the reproductive unit is more complex than was assumed by the original model. The family was initially assumed to be the unit of production, co-operating in the division of labor; the demands of the work-process therefore seemed to determine household structure and demographic behavior directly and necessarily. However, the co-operative division of labor did not invariably occur within the household, but could also occur between households. Houscholds could adapt, according to Kriedte, Medick, and Schlumbohm, to the requirements of work and survival not only through the demographic acts of marrying and begetting children, but also through the social acts of single children leaving home or the admission of persons who did not belong to the nuclear family. Furthermore, if men worked as peasants or agricultural laborers, and women were engaged in industrial work, marriage behavior might not be influenced by the requirements of one of these systems, but by a combination of both (Kriedte, Medick, and Schlumbohm 1993. p. 223). Garrett has suggested that rather than households adapting to the requirements of work, work was fitted around the family (Garrett 1990, p. 147). Individuals did not react to the requirements of work by demographic acts, but rather took up work that fitted their personal or family situation. 
Morris has pointed out that the "household strategy' perspective not only suffers from taking the household as an unproblematic unit for analysis. The voluntarism implied, as well as the implicit assumption of consensual decision making, are misleading when the limitations on households or individual choice are considered. The options available to households in their responses to economic change are narrow, and will vary by virtue of the characteristics of the local labor market, and the individual strengths and weaknesses within that market. The household is a constantly changing unit, and work provided by, and supplied to, different households is mediated by the stage in the domestic cycle (Morris 1990, pp. 20-21, 44).

As Ogilvie has pointed out, empirical studies using the original model showed that proto-industrialization did not always lead to population growth, and population growth occurred without proto-industrialization. According to the original theory, proto-industrialization led to earlier marriage, lower celibacy, and higher fertility because protoindustrial groups were supposed to be landless, and need not wait to inherit before setting up house. As Ogilvie showed, it is now clear that workers in many proto-industries retained the possibility of inheriting land, and thus did not lose their incentive to delay marriage (Ogilvie 1993, pp.159-179). Hendrickx showed that as long as the industrial economy was uncertain, people held on to peasant-like characteristics of spreading risks, retaining their original demographic behavior (Hendrickx 1993, pp. 321-355). The effects which protoindustry was supposed to have on marriage, fertility, and household structure have all failed to emerge from empirical study. Ogilvie showed that proto-industrialization has been reported to lead to either earlier or later marriage, to higher or lower fertility, and to either larger or smaller families and household. Proto-industry could even leave any or all of these variables unchanged (Ogilvie 1993, p. 174).

Discussion on whether marital behavior should be seen as part of family or household strategy, or more as an individual strategy obscures the fact that marital behavior may be influenced by different factors for men and women. Dixon has linked the occupational possibilities for women to the attractiveness of marriage. According to Dixon, when sufficient occupational possibilities were available, marriage proved less attractive or less necessary for women (Dixon 1970, pp. 15-39). Occupational possibilities need not be restricted to the realm of formal waged economy, but can also be related to help of unmarried women in the household of their mother or a married sister (Van Poppel 1992, pp. 224, 270). Nuptiality and the marital age are influenced by the possibilities to make use of unmarried children and siblings within the household.

\section{CHANGES IN OCCUPATIONAL POSSIBILITIES FOR WOMEN}

Changes in occupational possibilities open to women from the four villages will be discussed here from two perspectives. First, changes are discussed to measure a possible effect on marital behavior. Secondly, an attempt is made to estimate an effect on fertility. Below, changes in migration, proto-industry, and farming will be discussed by village or group of villages. Employment opportunities, both waged and unwaged, were not the same for women and men, not even for the young and the old family members. If no unmarried sisters, daughters, or grandmothers were available to work in the household, families could turn to hired maids, in the same way as farm hands were hired when no male relatives were at hand. However, Bourke found that widows were of more use to the household of her adult children, minding grandchildren and repairing stockings, than a widower could be to 
his. She found for Ireland that widowers as a result much more often ended up in a workhouse than widows (Bourke 1993, p. 272). Likewise, Schellekens found for eighteenthcentury Brabant that the only family-size variable which had a significant negative effect on living standards was the number of daughters aged eight to 15. She concluded that there were limited employment opportunities for daughters of this age both within and outside the household (Schellckens 1995, p. 209).

The use that could be made of unwaged work provided by female family members was not only influenced by, for instance, the size of the farm or the number of young children, but also by changes in maternal mortality. In Aarle-Rixtel and Bladel, for example, the age at which mothers died increased from, on average, 50 for the birth cohort 1811, to 67 for the birth cohort 1849. As women continued to have children well into their forties, this meant that in the earlier years women died when their last children were still young. Help of female relatives was called in to replace the missing mother. With less maternal mortality at a young age, the demand for this kind of help decreased in later years.

\section{MIGRATION}

Permanent migration from Brabant was relatively unimportant in the nineteenth century (Engelen and Klep 1996, pp. 59-76). Seasonal migration from the Meierij and migration within were, however, substantial. The effects of changes in the migration pattern on income options open to women, as well as on marital behavior and fertility, were different for the four villages, and will be discussed below by village.

In the beginning of the nineteenth century, hundreds of workers from the south of the Meierij, including Bladel, went annually to work in other regions of the Netherlands. According to Lucassen's estimates, the number of migrant laborers from the Meierij at the beginning of the nineteenth century was about 1500 (Lucassen 1984, p. 295). Both men and women found employment in agriculture, or went to work on the bleacheries. Men also worked as carpenters and masons. ${ }^{1}$ In the course of the nineteenth century, the demand for these migrant laborers decreased, and after 1870 the phenomenon had disappeared. The effect of the disappearance of this seasonal migration was threefold. First, migration as an income option for unmarried women disappeared. Second, as seasonal migration had involved more men than women, women who stayed behind had replaced men. Disappearance of seasonal migration meant that less work fell on women, or less options were open to them. Third, the disappearance also had a direct effect on fertility as marriages no longer needed to be forestalled until the end of the migration season (Van Poppel 1995). For married couples it, furthermore, could mean an increased frequency of intercourse.

Apart from seasonal migration, there was migration for a year or more, mostly to the south. Of the people born in Bladel in 1849, three quarters went to work outside the village for a year or more. The migrants, both men and women, were between the age of fifteen and twenty-nine. Many of these migrants went for more than one period, and some went away as many as eight times. One out of three migrants went to the neighbouring Belgian region, around the city of Turnhout. The young people who left were predominantly children of the non-agricultural population. Quite a few, especially women, did not return to their native Bladel.

Migrants were attracted to the important proto-industrial textile sector of the Turnhout region until about 1880 . This proto-industry had its own specialities. Arendonk, for 
instance, specialized in frame knitting of stockings. This was a skilled profession, requiring a long apprenticeship. After 1880, the textile sector in the Turnhout region slumped, but new industries sprung up: ceramic and chemical industries, and cigar making (Vanhaute 1991, pp. 28-49). It is remarkable that migrants from Bladel went to Turnhout and its surroundings, rather than to the industrializing regions within the Meierij, such as Tilburg and Eindhoven. It is unlikely that the reason for this was that there was no demand for labor in these towns, as the towns attracted many people from elsewhere. It is surprising that people from Bladel continued to go to the Turnhout region after the nature of its industry had changed, and the textile industry had lost its place to newer industries. If this industry had continued to prosper, specialized Bladel workers would have been in demand. However, although discontinuity prevailed over continuity, personal ties between the two regions remained. Friends and relatives were the intermediaries for finding work, and thus determined the direction the migrants went. Among the men, the very same people who had gone to the Turnhout region as stocking knitters, later went as cigar makers. For the women who had gone the Turnhout region this, however, changed as migrating cigar makers were, unlike the earlier textile workers, predominantly men. The collapse of the textile industry decreased the options that were open to the Bladel women.

From about 1860 , cigar making became the major new industry in Bladel itself. In the last quarter of the century, over a hundred men in Bladel officially worked in the profitable cigar industry. The real number was probably higher and included also women, although for them this new industry could not replace the work in the textile industry. Contrary to the textile industry, the cigar industry was situated in the village enabling people to stay in the place in which they were born. This change had important demographic consequences. The growth of the Bladel population accelerated after the rise of its cigar industry.

Migration in Aarle-Rixtel differed from that in Bladel. Of the birth cohort Aarle-Rixtel 1811, only very few young people migrated; of the birth cohorts 1849 and 1889 a third migrated for one or more periods. A third of these migrants went to Helmond. The rest went to neighboring villages. Migrants form Aarle-Rixtel went away less frequent than those from Bladel. In Aarle-Rixtel only a few migrants went away more than three times. These were agricultural laborers who were hired and fired at Lent. Of the rest, a few went away for a couple of years, but most migrated permanently from Aarle-Rixtel. The migration pattern from Aarle-Rixtel was to a large extent determined by the nature of the textile industry in the region. In the beginning of the nineteenth century, Aarle-Rixtel had both weavers and spinners. Weaving became more important as the nineteenth century progressed. It was mainly done by men, but there were also a few female weavers. In the course of the nineteenth century, the number of spinners in Aarle-Rixtel, mostly women, decreased, but the number of female factory workers working in the Helmond factories rose considerably. Furthermore, there was a noticeable increase in the number of female reelers. Until 1870 , most textile workers in the region worked in the putting-out system for factories in Helmond, and to a lesser extent in nearby Gemert and Asten. In the decades following 1870 , the putting-out system disappeared, and more and more people came to work inside the factories. The factories in Asten and Gemert, being less favorably situated, declined in importance. With the disappearance of the proto-industry the participation of married women in industrial work, mainly as reelers, ended. Construction of the tramway in 1890 greatly reduced migration from Aarle-Rixtel to Helmond, as it enabled people to continue living in Aarle-Rixtel while working in Helmond. Especially for young unmarried 
women commuting came to replace migration. As a result, like in Bladel, the population growth accelerated at the end of the nineteenth century.

Migration from Bladel and Aarle-Rixtel had it's demographic consequences. In the second half of the nineteenth century, the most productive age groups were underrepresented in both villages, and the sex ratio was unbalanced, with men outnumbering women. The result was the low birth rate (see Figure 3). After 1900, when there was less permanent migration of women, the sex-ratio became more balanced and the birth rate increased.

Contrary to Bladel and Aarle-Rixtel, migration from Schijndel and Veghel was rather unimportant with only some migrants working on farms in neighbouring villages. Migrants did not go to "s-Herlogenbosch to work, for instance, as domestic help, nor did migrants go to any of the textile towns in the Meierij. As the few young female workers who did migrate returned to Schijndel and Veghel, migration did not affect the birth rate as it did in the other two villages. An effect of the difference in migration pattern between the villages was that from Bladel and Aarle-Rixtel people from the lower strata moved away to find employment elsewhere as textile workers, whereas in Veghel and Schijndel they stayed. Thus, there were more marriages within the lower strata in Veghel and Schijndel. More marriages amongst the lower classes resulted in a higher death rate, as the chances of survival for lower class children were less than for those of the higher classes.

\section{PROTO-INDUSTRIAL WORK AND NEW HOME INDUSTRIES}

In the beginning of the nineteenth century, there were hundreds of spinners in Veghel and Schijndel, but only very few weavers. The number of spinners decreased sharply in the course of the nineteenth century. By 1869 , spinning had almost disappeared from Veghel and Schijndel. Unlike in Aarle-Rixtel, the spinning was not replaced by reeling or factory work. The spinners in Veghel and Schijndel worked in the putting-out system, mainly for factories in 's-Hertogenbosch. Although there were major fluctuations in the fate of the Meicrij's textile industry, the decline in the number of spinners was of a permanent nature. In Tilburg the work-force in the textile industry was reduced from 4650 in the beginning of 1810 , to 3325 in the beginning of 1813 . The loss was primarily accounted for by a reduction in the number of spinners; from 2100 to $15500^{2}$ This loss was not only due to a decreasing production, but also to improvements in the spinning technique (Van Gorp 1987, p. 93; Muntjewerff 1993). ${ }^{3}$ The increasing poverty outside the towns was attributed to changes in spinning techniques. In 1818 , both in Tilburg and in the neighbouring villages, complaints were heard that poverty had greatly increased due to the introduction of spinning machines. Some municipalities demanded a ban on these machines. ${ }^{4} \mathrm{~W}$ ith a stress on the relatively late introduction of steam power in the Dutch textile industry, the importance of changes in spinning technique has often been underestimated. Around 1800 , spinning in the Meierij made use of machines designed in England and France, and built in Belgium and the Meierij itself. ${ }^{5}$ These spinning machines did not require steam power for effective use. At the beginning of the nineteenth century, the Tilburg factories made use of mule jennies with eleven spindles. The factories in and around Eindhoven used the more advanced continuous wheels, with sixty spindles. The most advanced machines had an average of forty spindles to a spinner. ${ }^{6}$ As spinning had largely been a female profession in the Meierij, the introduction of spinning machines meant that the number of women needed in the industry greatly decreased. Each mule jenny replaced eleven spinning wheels. Sixty machines in 
Tilburg did the work of some 660 spinners on traditional spinning wheels. Near Eindhoven, 32 spinners on 21 wheels did the work of 1260 traditional spinners. Weaving, which was done by men, had at this point undergone less change, and had not affected the labor force in the same way.

For women, changes in the yarn twisting industry were also of importance. In the beginning of the nineteenth century the yarn twisting industry in " $\mathrm{s}$-Hertogenbosch and in nearby Waalwijk employed 6000 people. Most of these people worked only part-time for the factory. ${ }^{7}$ After 1816 , the industry collapsed due to imports from abroad. ${ }^{8}$ Like changes in the spinning technique, this change mostly affected women. Similar developments occurred in the ribbon making industry, which had likewise employed hundreds of women, and almost disappeared in the $1820 \mathrm{~s}$.

In the first half of the nineteen century, according to official statistics, some 20 percent of the work-force worked in the textile industry. As the employment of many women and children went unrecorded, this figure was probably higher in reality. Work in the Turnhout region, and seasonal migration to the textile industries in the north of the Netherlands are also not included. In the second half of the century, the importance of the industries in Tilburg, Eindhoven, and Helmond greatly increased, but that of 's-Hertogenbosch decreased. Seasonal migration and work in the Turnhout region likewise disappeared. Hence, the percentage will have increased in the course of the nineteenth century, but not as much as the growth of the industry in the larger lowns would suggest. Employment in the textile industry was far from stable, both for men and for women. The work done by women, however, did not only fluctuate in the manner of that of the men, but was also subject to permanent changes due to mechanization. Not only mechanization within the Meierij was important, but also that outside it, because mechanization elsewhere also resulted in less work in the Meierij. Women therefore had to look for alternative means of employment on a permanent basis. Schijndel and Veghel gained a new domestic industry in the course of the nineteenth century: clog making. Clogs were already an important article of export from the Meierij to the northern provinces in the eighteenth century. The fact that a cross-breed of the Canadian poplar and the local black poplar did well on the sandy Meierij soil was the origin of this specialization. In the nineteenth century the demand for clogs, as a cheap form of foot wear, increased. At the end of the century some hundred clog makers worked in Schijndel and another hundred in Veghel. With little technical innovation, and no concentration of production, the expanded demand for clogs led to an increase in the number of workers involved in clog making, and the rise of a new domestic industry, mainly creating work for self-employed men (van Puijenbroek 1969, p. 50).

More noticeable than the expansion of clog making was the proliferation in jobs. As the nineteenth century progressed, the diversity of jobs open to men in Schijndel and Veghel increased. Through the years, the size of enterprises of artisans did not increase much, but the scope of professions open to men widened. The construction of a better infrastructure also required many workers. When finished, the new connections gave work to teamsters, boatmen, and railway and tramway personnel. The number of people thus employed rose considerably in the second half of the nineteenth century. Furthermore, the better infrastructure both resulted from, and caused specialization. Autarchy declined, and more people began to depend on the market. As a result the number of shopkeepers and tradesmen increased. Specialization also caused expulsion of tasks from the agricultural household, for instance the baking of bread, or the brewing of beer, decreasing the tasks of 
women within the household. The disappearance of home brewing, which had been done by women on a large scale (Schrover 1995, p.178), also led to a decrease in hop growing, in which Schijndel and Veghel had specialized. Hop-picking had been women's work.

\section{FARMING}

Since agriculture was important for nineteenth- and twentieth-century Meierij, it is worthwhile to see whether, and, if so, how the nature of farm work for women changed (cf. I.ee 1990, pp. 50-75). Farming was more profitable in a wide circle around "s-Hertogenbosch, including Schijndel and Veghel, than in the regions more to the south and east. Farmers near 's-Hertogenbosch already specialized in cattle breeding in the beginning of the nineteenth century. In the more southern regions, including Bladel, there were more waste lands, and the yield per acre was lower. In the north there were more cows and pigs; in the south there were more sheep per farm. In the north, the soil was more fertile, the infrastructure was better and there was a larger demand from a non-agricultural population (Trienckens 1985, pp. 2-14).

In the course of the nineteenth century, agricultural work on farmsteads was separated from many other tasks. At the end of the nineteenth century, expulsion and specialization had changed farm work considerably from what it had been at the beginning of the century. This is a change that does not show up in statistics, where a farmer is a farmer regardless of what he or she actually does.

In the beginning of the nineteenth century large quantities of rye, buckwheat, and butter were exported from the region to the northern provinces, despite the sandy nature of parts of the Meierij's soil (Van Hogendorp 1854, p. 12). In order to improve the quality of the soil, manure or fertilizer was made and bought. Meierij farmers were experts in increasing the amount of manure. Cows were kept inside the barn, and fed with a broth cooked in large kettles by women farmers from products grown specially as cow fodder. By keeping cattle in the barns most of the time, collecting all the droppings in a layer of straw, and mixing it with turf or heather sods, the farmers managed to collected and utilize all manure. This way of keeping cattle was introduced around 1800 . Broth feeding was a task of women, and its introduction created much work for them. With more manure, production per acre increased, and consequently more cattle could be kept, setting an upward spiral in motion. In the last quarter of the nineteenth century, artificial and imported natural fertilizers were introduced in the Meierij. By the end of the century broth feeding had virtually disappeared, greatly reducing women's lasks on the farm.

Cows were kept to be sold for meat and for the production of butter. As a result of improved feeding techniques for cattlc, the Meierij became an important producer of young cattle and butter carly in the nineteenth century (Beschreeve staat van de Meijerij 1794, pp. 434-435). Many thousands of kilograms of butter were exported from the Meierij to Middelburg and Rotterdam, and from there to England. Large amounts of butter were produced on farms in the Meierij throughout the nincteenth century. The sale of butter was an important source of income for the farmers. In the beginning of the nineteenth century, these revenues were often the only money income farmers had. Butter making was the realm of women. They were not only in charge of making butter, but often also controlled its sale, either to engrossers, or on the local market. At the end of the ninetcenth century butter production moved from farms to factories. Strikingly, butter production in 
factories became men's work. Women did not find employment in the new factories (Schrover 1995, pp.170-193). The change from farm to factory production of butter, relieved women on farms from one of their most strenuous and important tasks.

When butter production moved to factories the skimmed milk was returned to the farmers. The skimmed milk was important for rearing animals, but was also used for human consumption. In fact, this practice may have affected infant mortality. Meierij farms were reputed to be unhygienic. The centralized processing of the milk, and redistribution of skimmed milk amongst the suppliers, may have caused infectious diseases to spread more easily from one farm to another.

The harvest of grains had always involved the labor of women. Here the change from the general use of the sickle, which was utilised by women, to the scythe, which was only used by men, may have resulted in a reduction of women's tasks. A more important change was the introduction of potatoes in the second half of the eighteenth century. Potatoes required more work, but also had a larger caloric yield per acre than grains. Moreover, potatoes were well suited for the Meierij soil causing the population to increase, and enabling people to live off smaller and poorer plots of land. However, it also meant that people were struck hard by the potato failure of 1845 . Although there was an overall decrease in marriage frequency in the Netherlands in the $1840 \mathrm{~s}$, Brabant stands out with a sharper and longer lasting decrease. It took Brabant until 1856 to recover (Engelen and Klep 1996, pp. 59-76; Hofstee 1983 , p. 51). The fact that Brabant was struck harder by the potato failure explains the widening of the gap between the curve of the birth rates for the Netherlands and that of Brabant in the period 1845 to 1860 (see Figure 2). Dependency on potatoes increased the depth of the crisis in the middle of the nineteenth century, but also allowed for periods of population growth at the beginning and the end of that century.

In the course of the nineteenth century, some farmers started to specialize in pig raising. Specialization was encouraged by the agricultural crisis, which started in 1878 and lasted until 1895. Due to large imports, grain prices dropped, stimulating farmers to look for more profitable alternatives. The prices of meat, cattle and dairy products did not drop as much as that of grain. In the period from 1850 to 1885 , pig raising had been a subsidiary tasks for many farmers. There were also several day laborers who kept a pig. In winter, the pig was slaughtered, and the best pieces of meat were sold. The rest was preserved and consumed within the household. This preservation was a task for women. When farmers specialized in pig raising, at the end of the nineteenth century, the slaughtering and processing of the meat moved from the farm to the large slaughterhouses, reducing the task of women considerably.

Towards the end of the nineteenth century chicken farming became much more important for the Meierij. In chicken farming, women had an important task. This work was, however, much less strenuous than broth feeding cattle, butter making, and the work that came with the slaughtering season.

Veghel and Schijndel had a flax culture of some importance. Flax growing was very demanding on farmers, especially on women. It could only be done on good quality soil, and required much care in the form of weeding. When they were ripe, the plants were pulled out of the soil, and stacked on the fields to dry for three weeks. They were pulled over a ripple to comb out the seeds. Then they were soaked in water to rot for a fortnight, roasted over a fire, and scutched. In flax culture both men and women were involved, but some of the very hard tasks fell on women. After 1870, flax became less important as an 
agricultural product in Veghel and Schijndel, greatly relieving the burden on the agricultural population, especially women (Crijns and Krielaars 1987, pp. 192-195).

\section{CONCLUSION}

The sustained high infant mortality at the end of the nineteenth century in the Meierij has attracted much attention. The high mortality set the Meierij apart from the rest of the Netherlands and from modernizing northern Europe. At the end of the nineteenth century infant mortality was not the only demographic characteristic that set the Meierij apart, as also nuptiality and fertility rose whilst they declined elsewhere. In recent years a change in feeding habits has become the accepted explanation for the high infant mortality. The only proof offered for the change in feeding habits is a decrease in the length of the interval between births, which is used as a proxy for lactation. According to the breastfeeding hypothesis women stopped breastfeeding their children thus increasing their fertility, but also raising infant mortality as bottlefed children were exposed to higher health risks. There was no increase in factory work for married women that could explain this change is habits. Therefore it was suggested that this change must have been the result of the influence of the clergy, who discouraged women from nourishing their children. There is no proof for this hypothesis apart from the length of the interval between births. The length of the interval is, however, not only influenced by lactation. The length of the interval is influenced by many other factors. It depends on the number of miscarriages and stillbirths. It depends on the frequency of intercourse which is influenced by, for instance, the disappearance of seasonal migration. It also depends on the marital age of women. The number of stillbirths, infant deaths, and miscarriages, and the fecundity and maternal mortality are related phenomena. All of these are influenced by the physical condition of women. Only infant mortality is influenced by a change in feeding habits. This makes the breastfeeding hypothesis not only unlikely and ill proven, but also insufficient.

Fertility not only increased because women married younger, at an age at which they were more fertile, but also because the physical condition of women improved. In the course of the nineteenth century, some of the tasks of women, especially on farms, moved to men, both inside and outside the farms. This explains both the lower marital age and the, partly related, increased fertility. With fewer premarital occupational possibilities, both in the formal waged economy and in the unwaged economy, women were more inclined to marry, or there was less pressurc on them to forestall a marriage. The opportunity costs of marriage for women decreased, making marriage a more attractive alternative. Limited altematives to married life increased women's inclination to marry. The possibility of marrying was supported by a concomitant widening of the occupational options open to men. As a result the marital age of women fell. Married women were, furthermore, released from some of their most strenuous tasks. Fewer stillbirths and miscarriages, but also an overall better physical condition, reduced the length of the birth interval. Increased fertility, both because of a lower age and because of less physical hardship meant that more children were born into already large households, or with a higher birth rank. As with each birth the chance the child died increased, and children born later in marriage or into already large families were more likely to die, more and carlier marriages led to higher infant mortality. 


\section{ACKNOWLEDGMENTS}

Data for the article were collected by numerous volunteers working under the supervision of Dr. Gerard Trienekens of the University Utrecht. I thank all people who have collected data for this research, especially Tom van Vlerken in Aarle-Rixtel, Nico van limpt in Bladel, Toos van Bavel in Veghel, and Piet Heessels in Schijndel. Research for this article was funded by the Netherlands Organization for Scientific Research (NWO).

\section{NOTES}

1. RANB Archief leen- en tolkamer nr. 298. Eerste staten, houdende opgaven van koophandel, brouwerijen, fabrieken, nering, tappers, teul- en weilanden 1791.

2. RANB Archief Hultman, Van der Fosse en Van den Bogaerde $047.06 \mathrm{nr}$. 7 Staat en gesteldheid van de lakenfabrieken en die van andere wolle stoffen in 1810,1811, 1812, en 1813 Departement der Rhijn-monden.

3. RANB provinciaal bestuur 095.014793 Leningen uit het Fonds der Nationale Nijverheid voor instandhouding en uitbreiding van fabrieken.

4. RANB provinciaal bestuur $095.01 \mathrm{nr}$. 10591 Staat van de administratie der huiszittende armen in de gemeente 1818 .

5. ARA Archief Goldberg 2.21.006.51 inv. nr. 50 Tabellen der statisticke opgaven betrekkelijk de Industrie. Departement Den Dommel nrs. 249-309 1802; ARA Archief Goldberg 2.21.006.51 inv. nr. 43 Stukken hetreffende de verzameling van gegevens omtrent de nijverheid en den handel 1800-1802. RANB Archief Van de Mortel-De la Court, nr. 542 Precis statistique du Departement de Braband.

6. RANB Archief Hultman, Van der Fosse en Van den Bogaerde 047.06 nr. 7 Staat en gesteldheid der Catoen-Fabrieken in de jaeren 1810,1811, 1812 en 1813.

7. RANB Archief Hultman, Van der Fosse en Van den Bogaerde 047.06 nr. 7 Staat der Gesteldheid der Gaarenlintfabrieken gedurende de jaaren 1810, 1811, 1812 en 1813; Staat en gesteldheid der gaarentwijnderijen in het Departement der Rhijnmonden over 1810, 1811, 1812 en 1813.

8. RANB provinciaal bestuur 095.01 Statistiek betreffende de handel, fabrieken en trafieken in de gemeenten 1816; RANB provinciaal bestuur 095.01.4385 Vergelijkende staten van de producten der voornaamste Fabrijken en Trafijken in de Provincie Noord-Brabant 1815-1830. RANB provinciaal bestuur 095.01.4385 Statistiek betreffende de handel, fabrieken en trafieken in de gemeente 1817 .

\section{REFERENCES}

"Beschreeve staat van de Meijerij (1794)." 1965. Historia Agriculturae VIII Groningen, 434-435.

Boonstra, O.W.A. 1993. De waardij van eene vroege opleiding. Een onderzoek naar de implicaties van het alfabetisme op het leven van inwoners van Eindhoven en omliggende gemeenten, 1800-1920. Wageningen: Agricultural University.

Bourke, Joanna. 1993. Husbandry to Housewifer: Women. Economic Change, and Housework in Ireland, 1890-1914. Oxford: Clarendon.

Buissink, J.D. 1970. De analyse van regionale verschillen in de huwelijksvruchtbaarheid. Een methodologisch-historische verkenning. Delft: Delftsche witgevers maatschappy.

Coale, A.J., and R. Treadway. 1986. "A Summary of the Changing Distribution of overall Fertility, Marital Fertility and the Proportion Married in the Provinces of Europe." Pp. 31-181 in The Decline of Fertility in Europe: The Revised Proceedings of a Conference on the Princeton European Fertility Project, edited by A.J. Coale and S.C. Watkins. Princeton.

Crijns, A.H., and F.W.J. Krielaars. 1987. Het gemengde landbouwbedrijf op de zandgronden in Noord-Brabant 1800-1885. Tilburg: Stichting zuideliyk historisch contact. 
Dixon, R.B. 1970. The Social and Demographic Determinants of Marital Postponement and Celibacy: A Comparative Study. Berkeley: University of California Press.

Duijvendak, Maarten, and Pim Kooij. 1992. Sociale geschiedenis. Theoie en thema's. Assen: Van Gorcum.

Engelen, Th.L.M., and J.H.A. Hillebrand. 1986. "Fertility and Nuptiality in the Netherlands, 18501960." Population Studies 40: 487-503.

Engelen, Th.I.M., and P.M.M. Klep. 1996. "Een demografisch traditionele samenleving." Pp. 61-76 in Geschiedenis van Noord-Brabant, part 1. 1796-1890 Traditie en modernisering, edited by H.F.J.M. van den Eerenbeemt. Amsterdam: Boom.

Garret, Eilidh M. 1990. "The Trials of Labor: Motherhood Versus Employment in a Nineteenth Century Textile Centre." Continuity and Change 5 (1): 121-154.

Gorp, P.J.M. van. 1987. Tilburg. eens de wolstad van Nederland. Bloei en ondergang van de Tilburgse wollenstoffenindustrie. Eindhoven: Bura Boeken.

Groot, G. de, and M. Schrover, 1995. "Between Men and Machines: Women Workers in New Industries, 1870-1940." Social History 20: 279-296.

Heijden, C.G.W.P. van der. 1995. Het heeft niet willen grocien. Zuigelingen-en kindersterfte in Tilhurg, 1820-1930. Omvang, ooraaken en maatschappelijke context. Tilburg: Stichting zuidelijk historiah contact.

Hendrickx, François M.M. 1993. "From Weavers to Workers: Demographic Implications of an Economic Transformation in Twente (the Vetherlands) in the Nineteenth Century." Continuity and Change 8: $321-355$.

Hofstee, E.W. 1978. De demografische ontwikkeling van Nederland in de eerste helft van de negentiende eeun: Een historisch-demografische studie. Arnhem: Van Loghum Slaterus.

1983. "Geboorten, zuigelingenvoeding en zuigelingensterfte in hun regionale verscheidenheid in de 19de eeuw." Bevolking en Gezin (supplement): 7-60.

Hogendorp, Gijsbert Karel Grave van. 1854. Bijdragen tot de huishouding van staut in het Koninkrijk der Nederlanden, verzameld ten dienste der Staten Generaul. Zaltbommel.

Huck, Paul. 1995. "Infant Mortality and Living Standards of English Workers During the Industrial Revolution." Journal of Economir History 55: 529-550.

Ildefonsus, Pater. 1926. Zuigelingensterfte en calcoholisme in Noord-Brabant. Helmond: Sobrietas.

Kintner, Hallie J. 1985. "Trends and Regional Differences in Breastfeeding in Germany from 1871 to 1937." Journal of Family History 10:163-182.

Kriedte, Peter. Hans Medick, and Jürgen Schlumbohm. 1992. "Sozialgeschichte in der Erweiterung Proto-Industrialisierung in der Verengung? Demographic, Sozialstruktur, moderne Hausindustrie: eine Zwichenbilanz der Proto-Industrialisierungs-Forschung." Geschichte und Gesellschaft 18: 70-87, 231-255.

1993. "Proto-Industrialization Revisited: Demography, Social Structure, and Modern Domestic Industry." Continuity and Change 8: 217-252.

Knodel, John. 1977. "Breastfeeding and Population Growth." Science 198: 1111-1115.

1988. Demographic Behavior in the Past: A Study of Fourteen German Village Populations in the Eighteenth and Nineteenth Centuries. Cambridge: Cambridge University Press.

Lee, W.R. 1990. "Women's Work and the Family: Some Demographic implications of GenderSpecific Rural Work Patterns in Nineteenth-Century Germany." Pp. 50-75 in Women's Work and the Family Economy in Historical Perspective, edited by Pat Hudson and W.R. Lee. Manchester: University of Manchester Press.

Lesthaeghe, R. 1983. "De borstvoeding als verklaring voor regionale verschillen in vruchtbaarheid en zuigelingensterfte: Nederland en België in het midden van de XIXe eeuw." Bevolking en Gezin (supplement): 61-84. 
Lesthaeghe R., and H.J. Page. 1980. "The Postpartum Non-Susceptible Period: Development and Application of Model Schedules." Population Studies 34: 143-169.

Lucassen, Jan. 1984. Naar de kusten van de Noordzee. Trekarbeid in Europees perspectief, 1600-1900. Gouda. Also published as Lucassen, Jan. 1987. Migrant Labour in Europe 1600-1900. London: Crome Helm.

Medick, H. 1976. 'The Proto-Industrial Family Economy; The Structural Function of Household and Family During the Transition from Peasant Society to Industrial Capitalism." Social History 2: 291-315.

Meurkens, P.C.G.M. 1984. Sociale verandering in het oude Kempenland (1840-1910) Demografie, economie en cultuur van een preindustriële samenleving. Nijmegen.

1985. Bevolking, economie en cultuur van het oude Kempenland. Bergeij: Stichting Eicha.

1989. "Kinderrijk en katholiek. De stijging van de huwelijksvruchtbaarheid in het Kempenland, 1830-1920." Pp. 117-130 in Werk, kerk en bed in Brabant. Demografische ontwikkelingen in oostelijk Noord-Brabant 1700-1920, edited by G.J.M. van den Brink, A.M.D. van der Veen, and A.M. van der Woude. Den Bosch: Stichting Brabantse regionale geschiedbeoefening.

Morris, Lydia. 1990. The Workings of the Household. A US-UK Comparison. Cambridge: Cambridge University Press.

Muntjewerff, H.A. 1993. De spil waar alles om draaide. Opkomst, bloei en neergang van de Tilburgse familie-onderneming Wolspinnerij Pieter van Dooren 1825-1975. Tilburg: Stichting zuidelijk historisch contact.

Nault, François, Bertrand Desjardins, and Jacques Légaré. 1990. "Effects of Reproductive Behavior on Infant Mortality of French Canadians During the Seventeenth and Eighteenth Centuries." Population Studies 44: 273-285.

Ogilvie, Sheilagh C. 1993. "Proto-Industrialization in Europe." Continuity and Change 8: 159-179.

Poppel, F. van. 1982. "Sociale ongelijkheid voor de dood. Het verband tussen sociaal-economische positie en zuigelingen- en kindersterfte in Nederland in de periode 1850-1940." Tijdschrift voor Sociale Geschiedenis 8: 231-281.

1989. "Urban-Rural Versus Regional Differences in Demographic Bchavior. The Netherlands, 1850-1960." Journal of Urban History 15: 363-398.

1992. Trouwen in Nederland. Een historisch-demografische studie van de 19e en vroeg-20e $e e u w$. Wageningen: Agricultural University.

1995. "Seasonality of Work, Religion and Popular Customs: The Seasonality of Marriage in the Nineteenth-and Twentieth-Century Netherlands." Continuity and Change 10: 215-256.

Puijenbrock, F.J.M van. 1969. Onder de voet gelopen. Het ontstaan en verwynen van een kleinnijverheid in Nederland na 1800. De Brabantse klompenmakerij. Tilburg: Stichting zuidelyk historisch contact.

Schellekens, Jona. 1995. "Poverty and Family Size in Two Eighteenth-Century Dutch Villages." Continuity and Change 10: 199-214.

Schrover, Marlou. 1995. "Cooking Up Women's Work: Women Workers in the Dutch Food Industries 1889-1960." Pp. 170-192 in Women Workers and Technolological Change in Europe in the Nineteenth and Twentieth Centuries, edited by Gertjan de Groot and Marlou Schrover. London: Taylor and Francis.

Thornton, Patricia A., and Sherry Olson, 199I. "Family Contexts of Fertility and Infant Survival in Nineteenth-Century Montreal." Journal of Family History 16: 401-417.

Trienekens, G. 1985. "Het drieslagstelsel en de Vlaamse bouw op de zandgronden van de Meierij; een momentopname voor het begin van de modernisering van de landbouw rond 1860/1870." Brabants Heem 37: 2-14.

1993. "Integrale geschiedenis in wording. Aarle-Rixtel en Wanroij in de negentiende en het begin van de twintigste eeuw." Pp. 211-313 in Een pront wijf, een mager paard en een zoon op 
het seminarie. Aanzetten tot een integrale geschiedenis van oostelijk Noord-Brabant 1770 1914, edited by Jan van Oudheusden and Gerard Trienekens. Den Bosch. Stichting Brabantse Regionale gescheidbeofening.

Vandenbrocke, C., F. van Poppel, and A.M. van der Woude. 1981. "De zuigelingen- en kindersterfte in België en Nederland in seculair perspectief." Tijdschrift voor Geschiedenis 94: 461-491; also published in Bevolking en Gezin. 1983 (supplement): 85-115; and as "Le développement séculaire de la mortalité aux jeunes âges dans le territorie du Benelux." Annales de démographie historique 1983, pp. 257-289.

Vanhaute, Eric. 1991. "Wolverwerking op het Turnhoutse platteland (1750-1850). Enkele bedenkingen bij het verstomd proto-industrieel debat." Tijdschrift voor Sociale Geschiedenis 1: $28-49$.

Vooys, A.C. de. 1951. "De sterfte in Nederland in het midden de 19e eeuw." Tijdschrift van het Koninklijk Nederlandsch Aardrijkskundig Genootschap, pp. 223-271.

Woude, A.M. van der. 1970. "Bevolking en gezin in Nederland." Pp. 19-70 in De Nederlandse samenleving sinds 1815. Wording en samenhang, edited by F.L. van Holthoon. Assen: Van Gorcum. 